\title{
Predicting biomass of hyperdiverse and structurally complex central Amazonian forests - a virtual approach using extensive field data
}

\author{
Daniel Magnabosco Marra ${ }^{1,2,3}$, Niro Higuchi ${ }^{3}$, Susan E. Trumbore ${ }^{2}$, Gabriel H. P. M. Ribeiro ${ }^{3}$, Joaquim dos Santos ${ }^{3}$, \\ Vilany M. C. Carneiro ${ }^{3}$, Adriano J. N. Lima ${ }^{3}$, Jeffrey Q. Chambers ${ }^{4}$, Robinson I. Negrón-Juárez ${ }^{5}$, \\ Frederic Holzwarth $^{1}$, Björn Reu ${ }^{1,6}$, and Christian Wirth ${ }^{1,7,8}$ \\ ${ }^{1}$ AG Spezielle Botanik und Funktionelle Biodiversität, Universität Leipzig, Germany \\ ${ }^{2}$ Biogeochemical Processes Department, Max Planck Institute for Biogeochemistry, Jena, Germany \\ ${ }^{3}$ Laboratório de Manejo Florestal, Instituto Nacional de Pesquisas da Amazônia, Manaus, Brazil \\ ${ }^{4}$ Geography Department, University of California, Berkeley, USA \\ ${ }^{5}$ Climate Sciences Department, Lawrence Berkeley National Laboratory, Berkeley, USA \\ ${ }^{6}$ Escuela de Biología, Universidad Industrial de Santander, Bucaramanga, Colombia \\ ${ }^{7}$ German Centre for Integrative Biodiversity Research (iDiv) Halle-Jena-Leipzig, Leipzig, Germany \\ ${ }^{8}$ Functional Biogeography Fellow Group, Max Planck Institute for Biogeochemistry, Jena, Germany
}

Correspondence to: D. Magnabosco Marra (dmarra@bgc-jena.mpg.de)

Received: 4 August 2015 - Published in Biogeosciences Discuss.: 18 September 2015

Revised: 23 February 2016 - Accepted: 26 February 2016 - Published: 11 March 2016

\begin{abstract}
Old-growth forests are subject to substantial changes in structure and species composition due to the intensification of human activities, gradual climate change and extreme weather events. Trees store ca. $90 \%$ of the total aboveground biomass (AGB) in tropical forests and precise tree biomass estimation models are crucial for management and conservation. In the central Amazon, predicting AGB at large spatial scales is a challenging task due to the heterogeneity of successional stages, high tree species diversity and inherent variations in tree allometry and architecture. We parameterized generic AGB estimation models applicable across species and a wide range of structural and compositional variation related to species sorting into height layers as well as frequent natural disturbances. We used 727 trees (diameter at breast height $\geq 5 \mathrm{~cm}$ ) from 101 genera and at least 135 species harvested in a contiguous forest near Manaus, Brazil. Sampling from this data set we assembled six scenarios designed to span existing gradients in floristic composition and size distribution in order to select models that best predict $\mathrm{AGB}$ at the landscape level across successional gradients. We found that good individual tree model fits do not necessarily translate into reliable predictions of AGB at the landscape level. When predicting AGB (dry mass) over scenarios using our different mod-
\end{abstract}

els and an available pantropical model, we observed systematic biases ranging from $-31 \%$ (pantropical) to $+39 \%$, with root-mean-square error (RMSE) values of up to $130 \mathrm{Mg} \mathrm{ha}^{-1}$ (pantropical). Our first and second best models had both low mean biases (0.8 and $3.9 \%$, respectively) and RMSE (9.4 and $18.6 \mathrm{Mg} \mathrm{ha}^{-1}$ ) when applied over scenarios. Predicting biomass correctly at the landscape level in hyperdiverse and structurally complex tropical forests, especially allowing good performance at the margins of data availability for model construction/calibration, requires the inclusion of predictors that express inherent variations in species architecture. The model of interest should comprise the floristic composition and size-distribution variability of the target forest, implying that even generic global or pantropical biomass estimation models can lead to strong biases. Reliable biomass assessments for the Amazon basin (i.e., secondary forests) still depend on the collection of allometric data at the local/regional scale and forest inventories including speciesspecific attributes, which are often unavailable or estimated imprecisely in most regions. 


\section{Introduction}

Allometries describe how relationships between different dimensions (e.g., length, surface area and weight) of organisms change non-proportionally as they grow (Huxley and Teissier, 1936). The lack of proportionality arises from the fact that organisms change their shape while they grow (i.e., the dimensions differ in their relative growth rates). As one important application, allometric relationships can be used to relate simple dimensions of trees (e.g., diameter at breast height, $\mathrm{DBH}$, or tree total height, $H$ ) to dimensions more relevant for forest managers and basic ecological research, such as wood volume or whole tree biomass (Brown et al., 1989; Higuchi et al., 1998; Saldarriaga et al., 1998).

Allometric relationships and biomass estimation models can differ substantially between different tree species, especially in species-rich regions with a high variation in tree sizes and architectures such as in the tropical rainforests (Banin et al., 2012; Nelson et al., 1999; Poorter et al., 2003). This variation reflects differences in growth strategy and life history, such as tree species occupying different strata when mature (e.g., understory, canopy or emergent species), successional groups (SGs) (e.g., pioneer or light-demanding species, such as Cecropia spp. and Pourouma spp., in contrast to late-successional or shade-tolerant species, such as Cariniana spp. and Dipteryx spp.) or environmental microsites (Clark and Clark, 1992; King, 1996; Swaine and Whitmore, 1988).

Important and highly variable architectural attributes of tropical tree species include stem shape (e.g., slender to stout form), branch form and branching intensity (e.g., plagiotropic, orthotropic and unbranched), crown contour (e.g., round, elongated and irregular), crown position (e.g., understory, canopy and emergent), maximum DBH and $H$ (Hallé, 1974; Hallé et al., 1978). In addition, there is large variation in growth rate (the speed at which a certain tree volume is filled) and consequently in wood anatomy among species (Bowman et al., 2013; da Silva et al., 2002; Worbes et al., 2003). Wood density (WD), which is particularly important for biomass estimation, varies significantly across regions (Muller-Landau, 2004) and can differ between species by more than an order of magnitude (Chave et al., 2006). Given these sources of variation, it is not surprising that different allometries were reported when comparing species (Nelson et al., 1999), successional stages (Ribeiro et al., 2014), ontogenies (Sterck and Bongers, 1998) and regions (Lima et al., 2012). Unfortunately, transferring such estimation models to other contexts - other species, size ranges, life stages, sites or successional stages - typically leads to predictions that deviate strongly from observations, especially when the sampling design does not allow the selection of relevant data for proper estimation of the parameters of interest (Gregoire et al., 2016) or when predictor ranges are limited or neglected (Clark and Kellner, 2012; Sileshi, 2014).
In temperate and boreal forests, the size, ontogeny and site variations have been captured by the development of generic species-specific biomass estimation models (Wirth et al., 2004; Wutzler et al., 2008) based on data from hundreds of individuals from a single tree species. However, this approach is prohibitive in the tropics where thousands of tree species coexist (Slik et al., 2015; ter Steege et al., 2013). Instead, the challenge is to develop generic local or regional formulations that also generalize across species (Higuchi et al., 1998; Lima et al., 2012; Nelson et al., 1999; Saldarriaga et al., 1998). Ideally, they contain predictor variables that (1) jointly capture a large fraction of the variation induced by the underlying morphological and anatomical gradients and (2) are still easy enough to obtain or measure.

The development and application of such generic models pose a number of challenges. Finding the appropriate model structure and estimating the model parameters requires a data set with a large number of individual measurements containing the variable of interest (here aboveground biomass, or AGB) and the predictor variables (i.e., DBH, $H$, species' SGs and WD). Importantly, the data set should ideally cover all possible real-world combinations of predictor values in order to avoid error-prone extrapolations and unreliable predictions. However, in multiple regression models, this precondition is rarely met, not even by large design matrices.

The ultimate prediction is typically at the landscape level, which requires summing up individual predictions for several thousands of trees varying in size and species assignment. The larger the variation of predictor values within a stand, the higher is the likelihood that extrapolation errors occur. This calls for a validation at the landscape level, which requires a plot-based harvest method. For obvious reasons, this has rarely been attempted (Carvalho Jr. et al., 1995; Chambers et al., 2001; Higuchi et al., 1998; Lima et al., 2012).

Notable effort has already been made to parameterize global/pantropical AGB estimation models (Brown et al., 1989; Chave et al., 2005, 2014). Commonly, these models are derived using several different data sets, each of which is comprised of relatively few trees and species. Although few opportunities exist to evaluate theses models at the landscape level, they are used worldwide in different contexts, sites and across successional stages. For instance, the pantropical model from Chave et al. (2005) (DBH + WD as predictors) overestimated biomass when tested against trees in Gabon (Ngomanda et al., 2014), Peru (Goodman et al., 2014), Colombia (Alvarez et al., 2012) and Brazil (Lima et al., 2012), but it also underestimated the AGB in mixedspecies Atlantic Forest stands in Brazil (Nogueira Jr. et al., 2014).

The availability of such generic AGB estimation models applicable to many species and contexts is particularly important for management, ecological and biogeochemical research in tropical forest landscapes that encompass a particularly wide spectrum of floristic and structural variation. For example, in the central Amazonian terra firme forests, 1 ha 
of old-growth forest can hold more than 280 tree species $(\mathrm{DBH} \geq 10 \mathrm{~cm})$ (de Oliveira and Mori, 1999) with a wide range of architectures and anatomies (Braga, 1979; MullerLandau, 2004; Ribeiro et al., 1999). At the landscape scale, this region encompasses a mosaic of successional stages promoted by windthrows (Asner, 2013; Chambers et al., 2013; Negrón-Juárez et al., 2010; Nelson et al., 1994). Disturbed areas include a diverse set of species representing the range from new regrowth to adult survivors, thereby including different SGs (pioneers, mid- and late-successional species), tree sizes and with a broader range of architectures than old-growth forests (Chambers et al., 2009; Marra et al., 2014; Ribeiro et al., 2014). Once floristic composition changes and structural gradients increase to this extent, allometry becomes more complex and reliable landscapelevel biomass estimates rely on well-designed and welltested generic biomass models.

We report here a novel data set of 727 trees harvested in a contiguous terra firme forest near Manaus, Brazil. This data set includes biomass measurements from 101 genera and at least 135 tree species that vary in architecture and are from different SGs (pioneers, mid- and late successional). These trees span a wide range of DBH (from 5 to $85 \mathrm{~cm}$ ), $H$ (from 3.9 to $34.5 \mathrm{~m}$ ) and WD (from 0.348 to $1.000 \mathrm{~g} \mathrm{~cm}^{-3}$ ). We used this data set to parameterize generic AGB estimation models for central Amazonian terra firme forests applicable across species and a wide range of structural and compositional variation (i.e., secondary forests), using various subsets of the available predictors; i.e., size (DBH and $H$ ), SGs and WD.

We next evaluated our models, as well as the pantropical model from Chave et al. (2014) at the landscape level using a virtual approach. We created scenarios of simulated 100 1 ha forest plots by assembling subsets of the 727 knownbiomass trees in our data set. These scenarios were designed to span gradients in (1) floristic composition, by assembling stands with specific proportions of pioneer, mid- and latesuccessional species, and (2) size distributions of trees. We compared the known biomass of these forest assemblage scenarios to predictions based on the generic models, with the goal of answering the following questions.

1. Which variance modeling approach and combinations of predictors produced the best individual tree biomass estimation model?

2. Which model most reliably predicted AGB at landscape level, i.e., across successional gradients?

We expected that the best model, the one reducing both mean deviation and error of single and landscape-level biomass prediction, would require species-specific variables as well as an additional parameter allowing the modeling of heteroscedastic variance. Our approach and the independence of our data set allowed us to evaluate whether it is still important to build local/regional models or whether available pantropical/global models are suitable for landscape biomass assessments - under the assumption that they predict biomass satisfactorily over all sorts of tropical forest types and successional stages.

\section{Material and methods}

\subsection{Study site}

Our study site is located at the Estação Experimental de Silvicultura Tropical (EEST), a 21000 ha research reserve (Fig. 1) managed by the Laboratório de Manejo Florestal (LMF) of the Brazilian Institute for Amazon Research (INPA), Manaus, Amazonas, Brazil ( $\left.2^{\circ} 56^{\prime} \mathrm{S}, 60^{\circ} 26^{\prime} \mathrm{W}\right)$. Averaged annual temperature in Manaus was $26.7^{\circ} \mathrm{C}$ for the $1910-1983$ period (Chambers et al., 2004). Averaged annual precipitation ca. $50 \mathrm{~km}$ east of our study site was $2610 \mathrm{~mm}$ for the 1980 2000 period (da Silva et al., 2003) with annual peaks of up to $3450 \mathrm{~mm}$ (da Silva et al., 2002). From July to September there is a distinct dry season with usually less than $100 \mathrm{~mm}$ of rain per month. Topography is undulating with elevation ranging from ca. 50 to $140 \mathrm{~m}$ a.s.1. Soils on upland plateaus and the upper portions of slopes have high clay content $(\mathrm{Ox}-$ isols), while soils on slope bottoms and valleys have high sand content (Spodosols) and are subject to seasonal flooding (Telles et al., 2003). In contrast to floodplains (i.e., igapó and várzea) associated with large Amazonian rivers (e.g., Rio Negro and Rio Amazonas), valleys associated with streams and low-order rivers can be affected by local rain events and thus have a polymodal and unpredictable flood-pulse pattern with many short and sporadic inundations mainly during the rainy season (Junk et al., 2011).

The EEST is mainly covered by a contiguous closed canopy old-growth terra firme forest with high tree species diversity and dense understory (Braga, 1979; Marra et al., 2014). The terra firme forests are among the predominant forest types in the Brazilian Amazon (Braga, 1979; Higuchi et al., 2004) and ca. $93 \%$ of the total plant biomass is stored in trees with $\mathrm{DBH} \geq 5 \mathrm{~cm}$ (Lima et al., 2012; da Silva, 2007). The tree density (DBH $\geq 10 \mathrm{~cm})$ in the EEST is $593 \pm$ 28 trees ha $^{-1}$ (mean $\pm 99 \%$ confidence interval) (Marra et al., 2014). Trees larger than $100 \mathrm{~cm}$ in $\mathrm{DBH}$ are rare $(<1$ individual $\mathrm{ha}^{-1}$ ) and those with $\mathrm{DBH}>60 \mathrm{~cm}$ accounted for only $16.7 \%$ of the AGB (Vieira et al., 2004). In the study region, tree mortality rates can be influenced by variations in topography (Marra et al., 2014; Toledo et al., 2012). Floristic composition and species demography can also vary with the vertical distance from drainage (Schietti et al., 2013).

\subsection{Allometric data}

We used data from 727 trees harvested in this region (dos Santos, 1996; da Silva, 2007), each with measured biomass and predictor variables. This data set comprised 101 genera and at least 135 species with $\mathrm{DBH} \geq 5.0 \mathrm{~cm}$ (Table 1; all data 


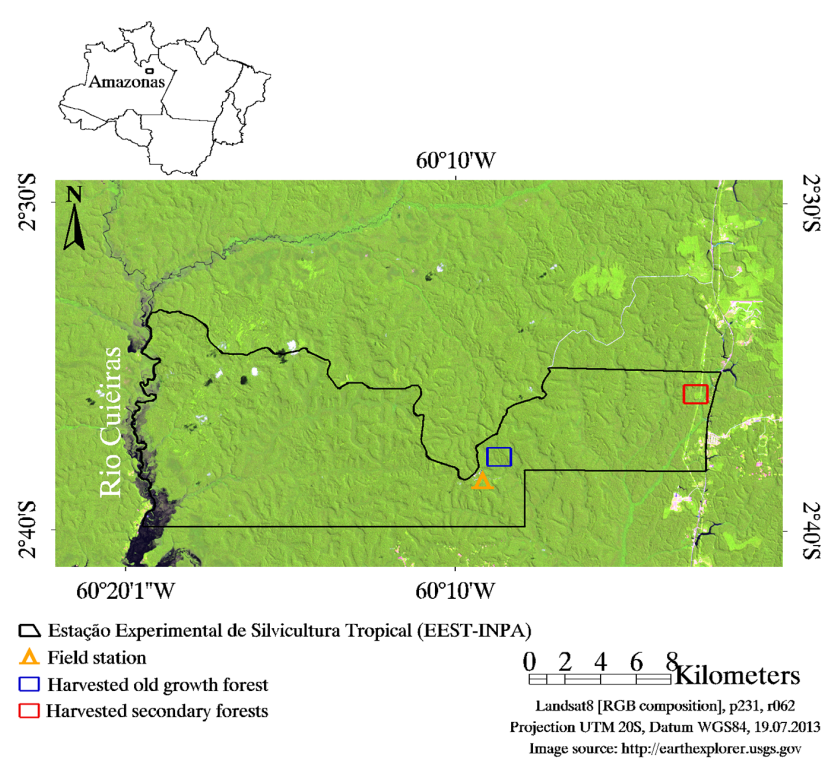

Figure 1. Study site of terra firme forest near Manaus, Amazonas, Brazil.

are given in Table S1 in the Supplement). The trees were harvested through the plot-based harvest method in an oldgrowth forest and in two contiguous secondary forests (14year-old regrowth following slash and burn and 23-year-old regrowth following a clear cut) (Fig. 1). Rather than an individual selection, our plot-based method relies on the harvesting of all trees found in selected plots. This method allows for a valid/faithful representation of the DBH distribution of the target forests and a landscape validation of the fitted models (Higuchi et al., 1998; Lima et al., 2012).

Before selecting plots, we surveyed both the old-growth and secondary forests to assure that no strong differences in structure and floristic composition existed and that the selected patches were representative of our different successional stages. In the old-growth forest the trees were harvested in eight plateau and three valley plots $(10 \mathrm{~m} \times 10 \mathrm{~m})$ randomly selected within an area of 3.6 ha (da Silva, 2007). In each of the secondary forests the trees were harvested in five plots $(20 \mathrm{~m} \times 20 \mathrm{~m})$, each randomly selected within a 1 ha plateau area (dos Santos, 1996; da Silva, 2007). By including trees from secondary forests we were able to increase the variation in floristic composition and consequently the range of species-related variation in architecture and allometry (Table 1 and Table S1). Since our secondary forests were inserted in the contiguous matrix from which old-growth plots were sampled, we also controlled for the effects of important drivers of tree allometry and architecture, such as variations in environmental conditions (e.g., soil, precipitation rates and distribution), forest structure and wood density (Banin et al., 2012); the last is intrinsically related to variation in floristic composition.
Table 1. Summary of the data set applied in this study. Trees were harvested in the Estação Experimental de Silvicultura Tropical, a contiguous terra firme forest reserve near Manaus, Amazonas, Brazil.

\begin{tabular}{llll}
\hline Variables & $\begin{array}{l}\text { Old-growth } \\
\text { forest }\end{array}$ & $\begin{array}{l}\text { Secondary forest } \\
(23 \text { years old })\end{array}$ & $\begin{array}{l}\text { Secondary forest } \\
\text { (14 years old })\end{array}$ \\
\hline NT & 131 & 346 & 250 \\
SR & 82 & 63 & 51 \\
DBH & $5.0-85.0$ & $5.0-37.2$ & $5.0-33.1$ \\
H & $5.9-34.5$ & $3.9-27.0$ & $9.0-15.5$ \\
WD & $0.348-0.940$ & $0.389-1.000$ & $0.395-1.000$ \\
AGB & $8.3-7509.1$ & $5.4-1690.2$ & $7.5-1562.8$ \\
\hline
\end{tabular}

Variables: number of trees (NT), species richness (SR), diameter at breast height (DBH) $(\mathrm{cm})$, tree total height $(H)(\mathrm{m})$, wood density (WD) $\left(\mathrm{g} \mathrm{cm}^{-3}\right)$ and aboveground biomass (AGB) (dry mass in kilograms).

Trees were harvested at ground level. For each tree, the DBH $(\mathrm{cm}), H(\mathrm{~m})$ and fresh mass $(\mathrm{kg})$ were recorded in the field by using a diameter tape, a meter tape and a mechanical metal scale $(300 \mathrm{~kg} \times 200 \mathrm{~g})$, respectively. The DBH was measured before, while $H$ was measured after harvesting. For trees with buttresses or irregular trunk shape, the diameter was measured above these parts. Each tree component (i.e., stem, branches and leaves) was weighted separately. For large trees, stems were cut into smaller sections before weighing. The mass of sawdust was collected and weighted together with its respective stem section. Leaves and reproductive material, when available, were collected to allow species identification accordingly to the APGIII system (Stevens, 2012). Botanical samples were incorporated in the EEST collection. The water content for each tree was determined from three discs ( $2-5 \mathrm{~cm}$ in thickness), collected from the top, middle and bottom of the bole, and samples (ca. $2 \mathrm{~kg}$ ) of small branches and leaves. The samples were oven dried at $65^{\circ} \mathrm{C}$ to constant dry mass. The dry mass data were calculated by using the corresponding water content of each component (Lima et al., 2012; da Silva, 2007). Dry mass for each tree was used for subsequent model fits and comparisons.

\subsection{Species' architecture attributes}

Each of our tree species or genera was assigned to one of three SGs known to vary in their architecture, namely pioneer, mid- and late-successional groups. To make this assignment, we considered several attributes related to species' architecture (i.e., shape and life history), growth position (i.e., stratum), morphology, wood density and ecology (Table S1 and Table S2). We validated this approach by checking our assignments against those of classic studies (Clark and Clark, 1992; Denslow, 1980; Saldarriaga et al., 1998; Shugart and West, 1980; Swaine and Whitmore, 1988), lo$\mathrm{cal} / \mathrm{regional}$ studies conducted in the Amazon (Amaral et al., 2009; Chambers et al., 2009; Kammesheidt, 2000; Marra 
et al., 2014) and species descriptions available in the Missouri Botanical Garden (http://www.tropicos.org), speciesLink (http://www.splink.cria.org.br) and Lista de Espécies da Flora do Brasil (http://www.floradobrasil.jbrj.gov.br/). More importantly, we considered empirical field observations, architectural information from our data set and data for species presence/absence from a network of permanent plots representing a wide range of successional stages in central Amazon (Table S2). This network includes plots in old-growth forests (LMF unpublished data (census from 1996 to 2012); da Silva et al., 2002), secondary forests (Carvalho Jr. et al., 1995; dos Santos, 1996), and small and large canopy gaps ( $\geq$ ca. $2000 \mathrm{~m}^{2}$ ) created by windthrows that are 4, 7, 14, 17, 24 and 27 years old (LMF unpublished data; Marra et al., 2014).

Since reported WD values for the same species or genera can vary strongly among different studies (Chave et al., 2006) and sites (Muller-Landau, 2004), we compiled WD values mainly from studies carried out in the Brazilian Amazon (Chave et al., 2009; Fearnside, 1997; Laurance et al., 2006; Nogueira et al., 2005, 2007). For species where WD data were not available for the Brazilian Amazon, we considered studies from other Amazonian regions (Chave et al., 2009). For species where no published WD was available, or where the identification was carried out to the genus level (63 in total), we used the mean value for all species from the same genus occurring in central Amazon. For trees identified only to the family level (seven in total), we used the mean value of genera from that family excluding those not reported in the study region (Table S1).

\subsection{Statistical analyses}

\subsubsection{Individual tree biomass estimation model fits}

The AGB estimation models we applied varied in the number and combination of our predictor variables (eight combinations/series) as well as the strategy of modeling the variance (three model types - see below), yielding a set of 24 candidate models (Table 2). We used DBH $(\mathrm{cm})$, WD $\left(\mathrm{g} \mathrm{cm}^{-3}\right)$ and $H(\mathrm{~m})$ as predictors. Furthermore, we used the species' SG assignment as a "categorical predictor" (factor 1 is pioneer, 2 is mid-successional and 3 is late-successional species), thereby representing functional diversity along a main axis of tree successional strategies, functional and architectural variation. Depending on the model-type parameters, the continuous variables were allowed to vary for capturing the successional aspects of functional diversity. We consider the SG grouping factor as integral part of the model. Fitting all SGs in one model in an Markov chain Monte Carlo context is different than fitting separate models because the joint model also absorbs the covariance structure of the parameters across groups, especially in models where not all parameters are allowed to vary among SGs.

We tested variables for collinearity by calculating the variance inflation factor (VIF). A conservative VIF>2.0 in- dicates significant collinearity among variables (Graham, 2003; Petraitis et al., 1996). Model series $1-4$ had VIF $<1.5$ (Table 2), which indicated no significant collinearity among predictors. For model series $5-8$, we found VIF $>2.0$ for DBH and $H$, which indicates significant collinearity between these two variables. This pattern was previously reported for other data sets from Amazon and other tropical regions (Lima et al., 2012; Ribeiro et al., 2014; Sileshi, 2014).

We fit models representing the eight different predictor combinations to our entire data set of 727 trees using three variance modeling approaches: nonlinear least square (NLS), ordinary least square with log-linear regression (OLS) and a nonlinear approach in which we modeled the heteroscedastic variance of the data set (MOV). In the MOV approach we modeled the variance as a function of DBH with a normally distributed residual error:

$\varepsilon_{i}=N\left(\hat{y}_{i}, \sigma_{i}\right)$,

where $i$ is the subscript for individuals $(i=1, \ldots, n)$ and $\sigma_{i}$ is modeled with a heteroscedastic variance according to

$\sigma_{i}=c_{\mathrm{i}} \cdot \mathrm{DBH}_{i}^{c_{2}}$.

Model series 1 (M11, M12 and M13) used DBH as the sole predictor (Table 2). For model series 2 (M21, M22 and M23), we allowed the $b$ regression parameters and $c$ heteroscedastic variance to vary according to the $\mathrm{SG}$ assignment $(1,2$ or 3). This approach allowed us to account for differences among the SGs without splitting the data set into three different groups. This method has increased analytical power and allowed us to assess the relationships between tree allometry and architecture.

For model series 3 (M31, M32 and M33), we ignored the SG assignment but introduced WD (which did not correlate strongly with SG). For model series 4 (M41, M42 and M43) we allowed each SG to have its own wood density effect. For model series 5 and 6 , we replaced the WD with $H$. In model series 5 (M51, M52 and M53), we restricted the SG variation of b and c, while in series 6 (M61, M62 and M63) we allowed these parameters to vary according to SG. For model series 7 (M71, M72 and M73), we combined DBH, $H$ and WD but restricted the SG variation of $b$ and $c$. Finally, for model series 8 (M81, M82 and M83), we combined DBH, $H$ and WD and allowed $b$ and $c$ to vary with SG (Table 2).

In contrast to prior approaches, we did not test models based on compound (e.g., $\log [\mathrm{AGB}] \sim \log [b 1]+$ $\left.b 2\left[\log \mathrm{DBH}^{2} \mathrm{HWD}\right]\right)$ or quadratic/cubic derivatives (e.g., $\log [\mathrm{AGB}] \sim \log [b 1]+b 2[\log \mathrm{DBH}]+b 3\left[\log \mathrm{DBH}^{2}\right]+$ $b 4\left[\log \mathrm{DBH}^{3}\right]$ ) (Brown et al., 1989; Chave et al., 2005, 2014; Ngomanda et al., 2014). These structures would have limited our ability to include biological variation by defining SGspecific parameters for DBH, $H$ and WD separately.

We fit the AGB estimation models with non-informative uniform priors using WinBUGS 1.4.3 (Lunn et al., 2000; Spiegelhalter et al., 2002). For each model, three chains were 
Table 2. Tested equations for estimating aboveground tree biomass (AGB) in a terra firme forest near Manaus, Amazonas, Brazil.

\begin{tabular}{|c|c|c|c|c|}
\hline Series & Model & Equation & $\begin{array}{l}\text { Variance } \\
\text { modeling (range) } \\
\text { approach }\end{array}$ & VIF \\
\hline \multirow[t]{3}{*}{1} & M11 & $\mathrm{AGB} \sim b 1 \mathrm{DBH}^{b 2}$ & NLS & 1 \\
\hline & M12 & $\log (\mathrm{AGB}) \sim \log (b 1)+b 2(\log \mathrm{DBH})$ & OLS & 1 \\
\hline & M13 & $\mathrm{AGB} \sim b 1 \mathrm{DBH}^{b 2}$ & MOV & \\
\hline \multirow[t]{3}{*}{2} & M21 & $\mathrm{AGB} \sim b 1[\mathrm{SG}] \mathrm{DBH} H^{b 2[\mathrm{SG}]}$ & NLS & 1.001 \\
\hline & M22 & $\log (\mathrm{AGB}) \sim \log (b 1[\mathrm{SG}])+b 2(\log \mathrm{DBH}[\mathrm{SG}])$ & OLS & 1.005 \\
\hline & M23 & $\mathrm{AGB} \sim b 1[\mathrm{SG}] \mathrm{DBH}^{b 2[\mathrm{SG}]}$ & MOV & \\
\hline \multirow[t]{3}{*}{3} & M31 & $\mathrm{AGB} \sim b 1 \mathrm{DBH}^{b 2} \mathrm{WD}^{b 3}$ & NLS & 1.007 \\
\hline & M32 & $\log (\mathrm{AGB}) \sim \log (b 1)+b 2(\log \mathrm{DBH})+b 3(\log \mathrm{WD})$ & OLS & 1.017 \\
\hline & M33 & $\mathrm{AGB} \sim b 1 \mathrm{DBH}^{b 2} \mathrm{WD}^{b 3}$ & MOV & \\
\hline \multirow[t]{3}{*}{4} & M41 & $\mathrm{AGB} \sim b 1[\mathrm{SG}] \mathrm{DBH}{ }^{b 2[\mathrm{SG}]} \mathrm{WD}^{b 3[\mathrm{SG}]}$ & NLS & $1.016-1.468$ \\
\hline & M42 & $\log (\mathrm{AGB}) \sim \log (b 1[\mathrm{SG}])+b 2(\log \mathrm{DBH}[\mathrm{SG}])+b 3(\log \mathrm{WD}[\mathrm{SG}])$ & OLS & $1.017-1.395$ \\
\hline & M43 & $\mathrm{AGB} \sim b 1[\mathrm{SG}] \mathrm{DBH}{ }^{b 2[\mathrm{SG}]} \mathrm{WD}^{b 3[\mathrm{SG}]}$ & MOV & \\
\hline \multirow[t]{3}{*}{5} & M51 & $\mathrm{AGB} \sim b 1 \mathrm{DBH}^{b 2} H^{b 3}$ & NLS & 3.382 \\
\hline & M52 & $\log (\mathrm{AGB}) \sim \log (b 1)+b 2(\log \mathrm{DBH})+b 3(\log H)$ & OLS & 3.342 \\
\hline & M53 & $\mathrm{AGB} \sim b 1 \mathrm{DBH}^{b 2} H^{b 3}$ & MOV & \\
\hline \multirow[t]{3}{*}{6} & M61 & $\mathrm{AGB} \sim b 1[\mathrm{SG}] \mathrm{DBH}{ }^{b 2[\mathrm{SG}]} H^{b 3[\mathrm{SG}]}$ & NLS & $1.019-3.439$ \\
\hline & M62 & $\log (\mathrm{AGB}) \sim \log (b 1[\mathrm{SG}])+b 2(\log \mathrm{BH}[\mathrm{SG}])+b 3(\log H[\mathrm{SG}])$ & OLS & $1.010-3.360$ \\
\hline & M63 & $\mathrm{AGB} \sim b 1[\mathrm{SG}] \mathrm{DBH}{ }^{b 2[\mathrm{SG}]} H^{b 3[\mathrm{SG}]}$ & MOV & \\
\hline \multirow[t]{3}{*}{7} & M71 & $\mathrm{AGB} \sim b 1 \mathrm{DBH}^{b 2} H^{b 3} \mathrm{WD}^{b 4}$ & NLS & $1.014-3.428$ \\
\hline & M72 & $\log (\mathrm{AGB}) \sim \log (b 1)+b 2(\log \mathrm{DBH})+b 3(\log H)+b 4(\log \mathrm{WD})$ & OLS & $1.038-3.469$ \\
\hline & M73 & $\mathrm{AGB} \sim b 1 \mathrm{DBH}^{b 2} H^{b 3} \mathrm{WD}^{b 4}$ & MOV & \\
\hline \multirow[t]{3}{*}{8} & M81 & $\mathrm{AGB} \sim b 1[\mathrm{SG}] \mathrm{DBH}{ }^{b 2[\mathrm{SG}]} H^{b 3[\mathrm{SG}]} \mathrm{WD}^{b 4[\mathrm{SG}]}$ & NLS & $1.523-3.624$ \\
\hline & M82 & $\log (\mathrm{AGB}) \sim \log (b 1[\mathrm{SG}])+b 2(\log \mathrm{DBH}[\mathrm{SG}])+b 3(\log H[\mathrm{SG}])+b 4(\log \mathrm{WD}[\mathrm{SG}])$ & OLS & $1.422-3.547$ \\
\hline & M83 & $\mathrm{AGB} \sim b 1[\mathrm{SG}] \mathrm{DBH} H^{b 2[\mathrm{SG}]} H^{b 3[\mathrm{SG}]} \mathrm{WD}^{b 4[\mathrm{SG}]}$ & MOV & \\
\hline
\end{tabular}

Predictors: diameter at breast height $(\mathrm{DBH})(\mathrm{cm})$, species' successional group (SG) (pioneers, mid- and late successional), tree total height $(H)(\mathrm{m})$ and wood density $(\mathrm{WD})$ $\left(\mathrm{g} \mathrm{cm}^{-3}\right)$. Variance modeling approach: nonlinear least square (NLS), ordinary least square with log-linear regression (OLS) and nonlinear with modeled variance (MOV). Since NLS and MOV rely on the same equation, they have analogue variation inflation factor values (VIF).

run in parallel, and convergence of the posterior distribution for each parameter was assessed by convergence of the ratio of pooled to mean within-chain central $80 \%$ intervals to 1 or by the stability of both intervals (Brooks and Gelman, 1998; Brooks and Roberts, 1998).

To select the best model we calculated the deviance information criterion (DIC). The DIC is a generalization of Akaike's information criterion and consists of a crossvalidatory term that expresses both the goodness of the fit and the models' complexity. The lower the value the higher the predictive ability and parsimony (Spiegelhalter et al., 2002). We also checked whether the $95 \%$ credible intervals of the parameter's posterior distributions excluded 0 . However, we did not attempt to test the null hypothesis that a particular parameter is 0 (Bolker et al., 2013; Bolker, 2008). Contrasts were evaluated by monitoring differences between parameters or predictions based on their posterior distribution. For communicating the results we consider two parameters significantly different if the $95 \%$ credible interval of the posterior distribution of their difference does not include 0 .

To allow for comparisons of different model structures and approaches with the available literature, we calculated the coefficient of determination $\left(R^{2}\right)$, the adjusted coefficient of determination $\left(R^{2} \mathrm{adj}\right)$ and the relative standard error $\left(S_{y x} \%\right)$. The $S_{y x} \%$ was calculated as follows:

$S_{y x \%}=\left(\frac{2 s}{\hat{y} \sqrt{N}}\right)$,

where $s, \hat{y}$ and $N$ are the standard deviation of the regression, the mean of the focal independent variable and the number of observations, respectively. As in all allometric data sets relating linear to volume-proportional data, there is indeed heteroscedasticity in our data, which restricts the use of the $S_{y x} \%$ for model selection. Nonetheless, this measure is prescribed for assessing models' uncertainty (IPCC, 2006) and is commonly used (Chave et al., 2014; Lima et al., 2012; Ribeiro et al., 2014; Sileshi, 2014).

For the OLS approach including log-transformed variables, we calculated the $S_{y x} \%$ using untransformed data. To correct for the bias introduced by the log-transformed data, a correction factor $(\mathrm{CF})$ was calculated as follows:

$\mathrm{CF}=\exp \left(\frac{\mathrm{SSE}^{2}}{2}\right)$,

where SSE is the standard error of the estimate (Sprugel, 1983). 

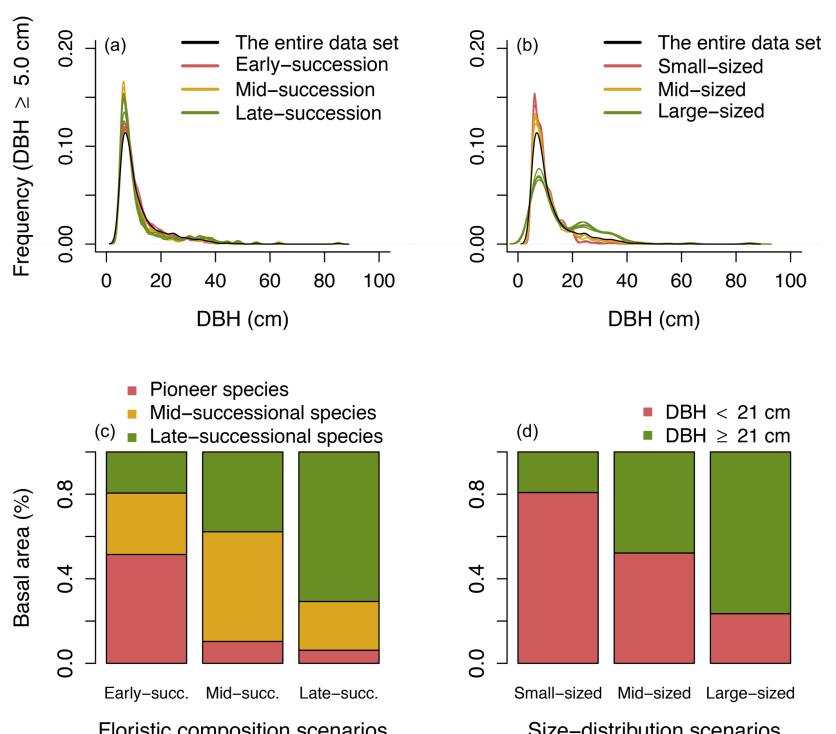

Figure 2. Sampling schemes applied to assemble the six forest scenarios designed to reflect changes in floristic composition and size distribution of trees, typical of central Amazonian terra firme forests.

\subsection{Landscape-level biomass predictions across scenarios}

To evaluate the models outlined in Table 2 , we predicted AGB at the landscape level for six forest scenarios assembled by a stratified random selection of individual trees from our data set of 727 trees. Our scenarios were designed to span a successional gradient created by natural disturbances in which the interaction of tree mortality intensity and species vulnerability and resilience produce complex communities varying in species composition and size distribution of trees (Chambers et al., 2009, 2013; Marra et al., 2014). We assembled three scenarios to reflect variations in floristic composition and three scenarios to reflect variations in size distribution. Each scenario was sampled 100 times, resulting in 1001 ha plots per scenario with different combination of trees randomly (with replacement) assembled according to the scenario-specific design principles.

To address the effect of variations in floristic composition on estimated AGB, we created scenarios where we varied the proportion of pioneer, mid- and late-successional species. The early-successional scenario comprised $50 \%$ from trees sampled randomly from the species classified as pioneer, $40 \%$ from mid- and $10 \%$ from late-successional species (as survivors of disturbances). The mid-successional scenario comprised $10 \%$ from trees sampled randomly from the species classified as pioneer, $70 \%$ from mid- and $20 \%$ from late-successional species. The late-successional scenario comprised $10 \%$ from trees sampled randomly from the species classified as pioneer, $40 \%$ from mid- and $50 \%$ from late-successional species (Fig. 2a and c). We con- strained our floristic composition scenarios to a stem density of 1255 trees ha $^{-1}(\mathrm{DBH} \geq 5 \mathrm{~cm})$ typical for the old-growth terra firme forests at the EEST (Lima et al., 2007; Marra et al., 2014; Suwa et al., 2012).

To address variations in size distribution, we varied the proportion of small and big trees fixing a threshold value of $21 \mathrm{~cm}$, which represents the mean DBH (trees with $\mathrm{DBH} \geq 10 \mathrm{~cm}$ ) of our studied forest (Marra et al., 2014). Our size-distribution scenarios included a small-sized stand, with $90 \%$ from small $(\mathrm{DBH}<21 \mathrm{~cm})$ and $10 \%$ from big trees $(\mathrm{DBH} \geq 21 \mathrm{~cm})$; a mid-sized stand with equal numbers of trees smaller and greater than or equal to $21 \mathrm{~cm}$ in DBH; and a large-sized stand, with $10 \%$ small and $90 \%$ big trees (Fig. $2 \mathrm{~b}$ and d). As for our floristic composition scenarios, in order to produce reliable size-distributions, we constrained our sampling effort to a basal area value of $30.3 \mathrm{~m}^{2} \mathrm{ha}^{-1}$ also typical of our studied old-growth forest (trees with $\mathrm{DBH} \geq 5 \mathrm{~cm}$ ) (Marra et al., 2014; Suwa et al., 2012). Both our floristic and size-distribution scenarios produced the $J$ inverse distribution pattern, typical of tropical forests (Clark and Clark, 1992; Denslow, 1980).

AGB at the landscape level was determined by adding up the measured AGB for "sampled" trees in each scenario. To test how well our biomass estimation models predicted the AGB at the stand level, we related biases and root-meansquare error (RMSE). In order to assess the accuracy of different predictions in the context of models' uncertainty, we additionally reported the overall performance of the tested models along all forest scenarios. When doing so, we present the bias and RMSE in the same unit (Mg), which allow for assessing the magnitudes of deviations in model predictions (Gregoire et al., 2016; McRoberts and Westfall, 2014). Because data on tree height are normally unavailable or estimated imprecisely in Amazonian forest inventories, we focused on models including only DBH, WD and SG as predictors (model series 1-4). In addition to the "internal evaluation" of our models, we tested the pantropical model from Chave et al. (2014):

$$
\begin{gathered}
\widehat{\log \mathrm{AGB}} \sim-1.803-0.976 E+0.976[\log \mathrm{WD}] \\
+2.673[\log \mathrm{DBH}]-0.0299[\log \mathrm{DBH}]^{2},
\end{gathered}
$$

which was parameterized with data from 4004 trees $(\mathrm{DBH} \geq 5 \mathrm{~cm})$ harvested in 53 old-growth and five secondary forests. This model has DBH, $H$ (estimated from a DBH : $H$ relationship), WD and a variable $E$ (environmental stress) as predictors and was suggested for estimating tree AGB in the absence of height measurements.

We performed all analysis using the $\mathrm{R}$ 3.2.1 software platform (R Core Team, 2014). We use the R2WinBUGS (Sturtz et al., 2005) package for running WinBUGS from $R$ and the ggplot2 package (Wickham, 2009) for producing figures, with the exception of Fig. 1, which was produced in the Environment for Visualizing Images software (ENVI, ITT Indus- 
Table 3. Statistics of aboveground biomass (AGB) estimation models fit in a terra firme forest near Manaus, Amazonas, Brazil. See Table 2 for predictors and applied variance modeling approaches and Table A3 for the models' parameters.

\begin{tabular}{llrrrrrrr}
\hline Series & Model & Dev & $\mathrm{pD}$ & $\mathrm{DIC}$ & $R^{2}$ & $R^{2}$ adj & $S_{y x \%}$ & $\mathrm{CF}$ \\
\hline 1 & M11 & 9694.5 & 2.919 & 9697.4 & 0.894 & 0.894 & 3.130 & \\
& M12 & 6808.0 & 2.990 & 6811.3 & 0.865 & 0.865 & 3.542 & 1.066 \\
& M13 & 6821.0 & 3.856 & 6825.2 & 0.864 & 0.864 & 3.544 & \\
2 & M21 & 9216.0 & 3.773 & 9219.9 & 0.946 & 0.945 & 2.259 & \\
& M22 & 6751.0 & 6.943 & 6758.3 & 0.557 & 0.540 & 6.458 & 1.061 \\
\multirow{3}{*}{3} & M23 & 6739.0 & 10.465 & 6749.5 & 0.558 & 0.554 & 6.381 & \\
& M31 & 9291.0 & 4.052 & 9294.7 & 0.949 & 0.939 & 2.373 & \\
& M32 & 6683.0 & 4.062 & 6687.0 & 0.885 & 0.884 & 3.280 & 1.056 \\
4 & M33 & 6698.0 & 4.918 & 6702.5 & 0.865 & 0.865 & 3.527 & \\
& M41 & 9057.0 & 2.303 & 9059.8 & 0.957 & 0.956 & 2.030 & \\
& M42 & 6657.0 & 10.006 & 6667.5 & 0.701 & 0.699 & 5.215 & 1.054 \\
5 & M43 & 6649.0 & 13.059 & 6661.6 & 0.701 & 0.699 & 5.239 & \\
& M51 & 9479.0 & 0.023 & 9479.3 & 0.921 & 0.921 & 2.702 & \\
& M52 & 6680.0 & 4.017 & 6684.3 & 0.899 & 0.898 & 3.060 & 1.055 \\
6 & M53 & 6720.0 & 4.674 & 6724.7 & 0.897 & 0.896 & 3.103 & \\
& M61 & 9183.9 & -71.746 & 9112.2 & 0.948 & 0.947 & 2.214 & \\
& M62 & 6614.0 & 10.078 & 6624.1 & 0.754 & 0.750 & 4.845 & 1.050 \\
7 & M63 & 6631.0 & 11.754 & 6642.9 & 0.740 & 0.737 & 4.896 & \\
& M71 & 8998.0 & 0.951 & 8999.1 & 0.959 & 0.959 & 1.942 & \\
& M72 & 6570.0 & 5.023 & 6574.9 & 0.934 & 0.933 & 2.480 & 1.047 \\
8 & M73 & 6610.0 & 5.697 & 6615.4 & 0.922 & 0.920 & 2.707 & \\
& M81 & 8812.0 & -42.073 & 8770.3 & 0.968 & 0.967 & 1.719 & \\
& M82 & 6548.0 & 13.031 & 6561.3 & 0.811 & 0.804 & 4.200 & 1.046 \\
& M83 & 6566.0 & 13.778 & 6580.0 & 0.801 & 0.800 & 4.262 & \\
\hline
\end{tabular}

Parameters: models' deviance (Dev), effective number of parameters (pD), deviance information criterion (DIC), coefficient of determination $\left(R^{2}\right)$, adjusted coefficient of determination $\left(R^{2}\right.$ adj), relative standard error $\left(S_{y x} \%\right)$ and correction factor $(\mathrm{CF})$ for models fit from ordinary least square with log-linear regressions.

tries, Inc, Boulder CO, USA). All codes used in this study were written by the authors.

\section{Results}

\subsection{Individual tree biomass estimation model fits}

Although the NLS approach produced models with overall higher values of $R^{2}$ and $R^{2}$ adj and lower values of $S_{y x} \%$, the DIC values indicated that the MOV and the OLS approaches produced the best models. The models M33 (DBH and WD as predictors) and M43 (DBH, SG and WD) were the two best fitting models across all tree individuals (high $R^{2}$ and $R^{2}$ adj and low $S_{y x} \%$ and DIC values compared to other models). These two models also produced more reliable landscape predictions (see Sect. 3.2). The statistics for the goodness of fit for the 24 models are given in Table 3. For the models fit with OLS, which rely on log-transformed variables, the addition of other predictors together with DBH systematically decreased the CF values. This pattern suggests a reduction in the biases resulting from back transformation.

As expected, the addition of other predictors to a model containing only DBH systematically increased the models' parsimony, as indicated by the lower DIC values (Table 3). The inclusion of the SG assignment resulted in models with slightly lower $R^{2}$ adj and higher $S_{y x} \%$ compared to the same model structure without SG.

We observed differences with respect to the parameters $\mathrm{b}$ and $\mathrm{c}$ among pioneer, mid- and late-successional species in most of the models that included the SG assignment (Table S3 and Fig. S1). The late-successional species tended to have higher intercepts and steeper slopes. Pioneer and midsuccessional species had lower differences in intercepts but still strong differences in the slopes.

Evaluations of AGB predictions for individual trees from our two best models (as described in the Sect. 3.2) as well from the pantropical model (Chave et al., 2014) are presented in the Supplement of this study (Fig. S1). The models M33 and M43 had lower biases (overestimation of 0.6 and $3.5 \%$, respectively) than the tested pantropical model (underestimation of $30 \%$ ).

\subsection{Landscape-level biomass predictions across scenarios}

To search for the model that best predicts AGB at the landscape level, we tested our models (excluding those with $H$ as 


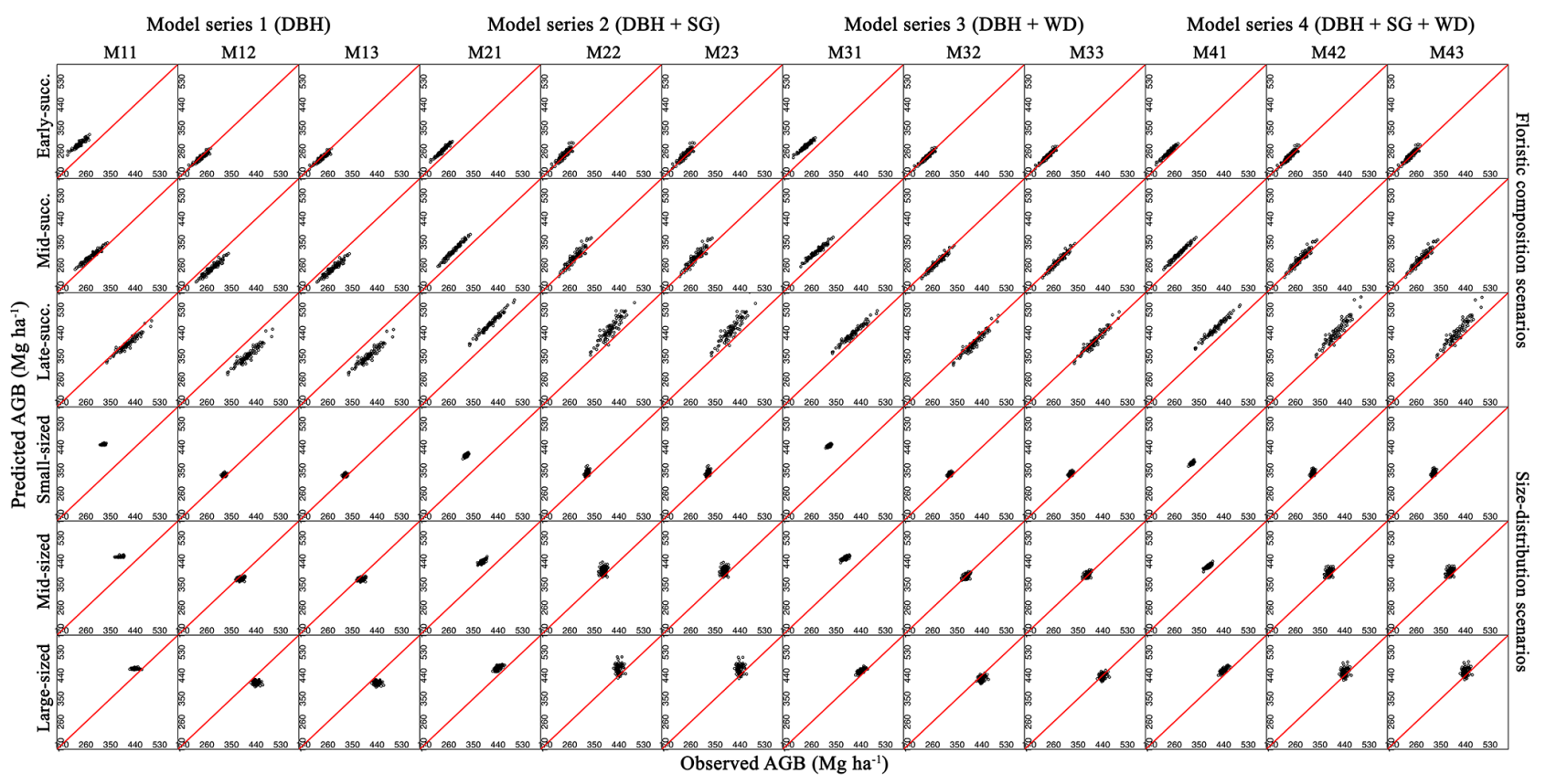

Figure 3. Predicted vs. observed aboveground biomass (AGB) along six forest scenarios composed of 1001 ha plots. The line of equality (1:1 line) is shown as a red/straight line. Forest scenarios were designed to reflect landscape-level variations in floristic composition and size distribution of trees, typical of central Amazonian terra firme forests. Floristic composition and size-distribution scenarios followed the sampling scheme described in Sect. 2.4.2 (Fig. 2) of this study. Models' predictors: diameter at breast height (DBH) (cm), species' successional group (SG) (pioneers, mid- and late successional) and wood density (WD) $\left(\mathrm{g} \mathrm{cm}^{-3}\right)$. See Table 2 for the variance modeling approach of different equations. Note that models containing tree total height $(H)$ as predictor were excluded here.

a predictor; Table 2) across the 1001 ha plots assembled for each of our six forest scenarios (Figs. 3-5) as well as jointly for all of them (Fig. 6).

The "true" AGB in our 1 ha plots (from the summed mass of trees used to assemble the forest scenarios) varied from 198.1 to 314.3 (early- to late-successional scenarios) and 101.4 to $391.8 \mathrm{Mg} \mathrm{ha}^{-1}$ (small- to large-sized scenarios). The ability of the various biomass estimation models to predict the "true" virtual biomass values generally reflected the goodness of fit of the models for predicting individual tree data (Table 3 and Figs. 3-6). The same pattern was observed when evaluating the tested pantropical model, which underestimated both the AGB of individual trees (Fig. S1) and in all of our scenarios (Table S4 and Fig. S2).

While some models produced accurate and satisfactory predictions across all scenarios, others systematically underor overestimated the observed AGB (Fig. 3 and Fig. S2). The agreement between models and observations was influenced not only by the different combinations of predictors but also by the different methods to model the variance. Interestingly, despite producing the best fits to the individual tree data, models fit with NLS produced the least reliable landscapelevel predictions, with model M11 (only DBH as predictor) being the unique exception for the mid- and late-successional scenarios (Fig. 3).
We observed systematic biases ranging from $-14 \%$ (underestimation) to $38.8 \%$ (overestimation) in estimated landscape-level AGB (Fig. 4). The models fit with NLS tended to overestimate landscape-level AGB, with biases ranging from -3.6 up to $38.8 \%$, both extreme values from model series 1 (only DBH as predictor). Overall, the models fit with NLS tended to capture changes in floristic composition better than in tree size distribution. The tested pantropical model systematically underestimated landscapelevel biomass, with a mean bias of $-29.7 \%$ (Table S4 and Fig. S2).

The models fit with the OLS and particularly with the MOV approaches were clearly more efficient at capturing the variation in floristic composition and size distribution of trees. Consequently, these models produced the most reliable landscape-level predictions within the scenarios (Fig. 3). As also indicated by the individual tree model fits, the MOV approach produced more reliable AGB predictions, especially with model series 2 and 4 .

In general, the models fit with the OLS and MOV approaches did not show systematic trends in under- or overestimation. The models fit with the OLS approach had biases ranging from -13.8 to $11.1 \%$, with extreme values from model series 1 and 2, respectively. The models fit with the MOV approach had biases ranging from -14 to $10.5 \%$, also 


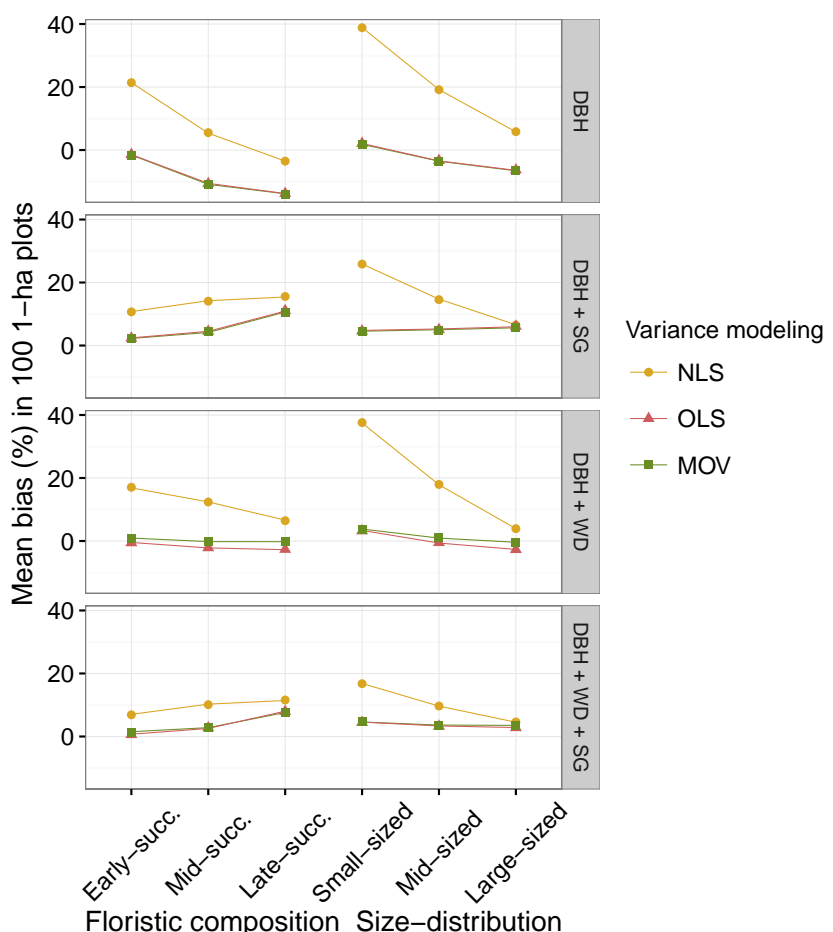

Figure 4. Profiles relating the bias of 12 aboveground tree biomass estimation models tested along six forest scenarios composed of 1001 ha plots. Forest scenarios were designed to reflect landscapelevel variations in floristic composition and size distribution of trees, typical of central Amazonian terra firme forests. Models' predictors: diameter at breast height $(\mathrm{DBH})(\mathrm{cm})$, species' successional group (SG) (pioneers, mid- and late successional) and wood density (WD) $\left(\mathrm{g} \mathrm{cm}^{-3}\right)$. Variance modeling approaches: nonlinear least square (NLS), ordinary least square with log-linear regression (OLS) and nonlinear with modeled variance (MOV). Note that models containing tree total height $(H)$ as predictor were excluded here.

with extreme values from model series 1 and 2, respectively (Fig. 4).

The reported systematic biases led to strong differences between the predicted and the observed AGB (Fig. 5). The models fit with NLS resulted in RMSE values ranging from 16.8 up to $125.8 \mathrm{Mg} \mathrm{ha}^{-1}$. For the models fit with OLS, the RMSE values ranged from 5.1 to $57.6 \mathrm{Mg} \mathrm{ha}^{-1}$. The MOV models had RMSE ranging from 5.5 to $58.7 \mathrm{Mg} \mathrm{ha}^{-1}$. The pantropical model's predictions had a mean RMSE of $102.6 \mathrm{Mg} \mathrm{ha}^{-1}$ (Table S4).

By combining the bias and RMSE values, we could observe the overall models' performance in predicting AGB across scenarios (Fig. 6). When challenged to predict biomass across all scenarios, the models fit with the MOV approach produced more reliable predictions (smaller range of biases and RMSE), except for model series 1 (only DBH as a predictor), for which the OLS approach performed better. Independently of applied predictors, the NLS approach had the highest mean and range of values for bias and RMSE.

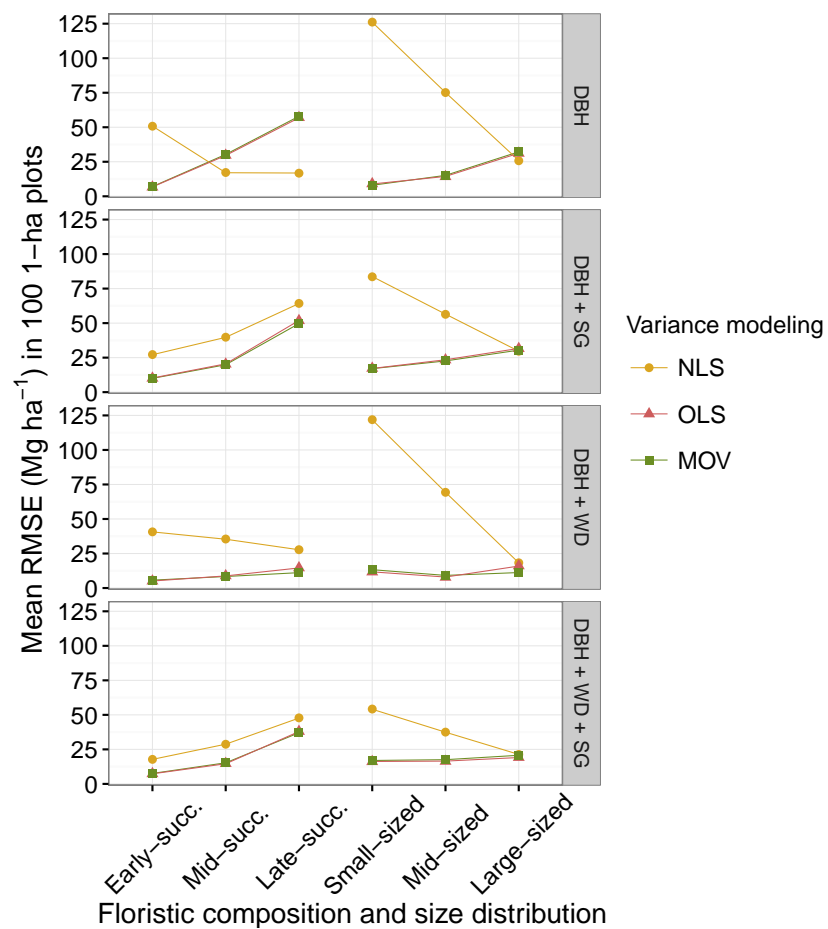

Figure 5. Profiles relating the root-mean-square error of 12 aboveground tree biomass estimation models tested along six forest scenarios composed of 1001 ha plots. Forest scenarios were designed to reflect landscape-level variations in floristic composition and size distribution of trees, typical of central Amazonian terra firme forests. Models' predictors: diameter at breast height $(\mathrm{DBH})(\mathrm{cm})$, species' successional group (SG) (pioneers, mid- and late successional) and wood density (WD) $\left(\mathrm{g} \mathrm{cm}^{-3}\right)$. Variance modeling approaches: nonlinear least square (NLS), ordinary least square with log-linear regression (OLS) and nonlinear with modeled variance (MOV). Note that models containing tree total height $(H)$ as predictor were excluded here.

As we expected, the addition of SG and WD improved the quality of the joint prediction. This was evidenced by the systematic reduction of models' bias and RMSE. Notably for the NLS approach, the inclusion of SG led to strong reduction of the bias and RMSE (Fig. 6). Interestingly, for this approach the addition of WD alone did not improve the estimations accuracy.

\section{Discussion}

\subsection{Individual tree biomass estimation model fits}

The best-performing allometry model structures for predicting the biomass of individual trees included species-specific predictors and either the OLS or MOV fitting approaches (Fig. 3, Fig. 6 and Table S3). As we hypothesized, including both the SG and WD as predictors greatly increased the models' performance. When taken alone, adding either 


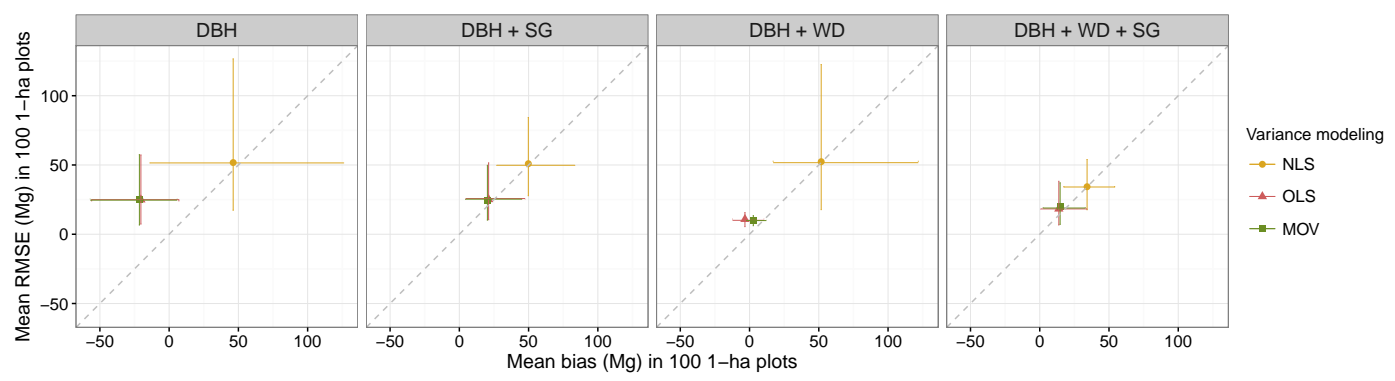

Figure 6. Overall performance of 12 aboveground tree estimation models along six forest scenarios composed of 1001 ha plots. Forest scenarios were designed to reflect landscape-level variations in floristic composition and size distribution of trees, typical of central Amazonian terra firme forests. Models are rated by the absolute mean bias and root-mean-square error (RMSE), both in Mg. Solid points and bars represent absolute mean and range values, respectively. Models' predictors: diameter at breast height (DBH) (cm), species' successional group (SG) (pioneers, mid- and late successional) and wood density (WD) $\left(\mathrm{g} \mathrm{cm}^{-3}\right)$. Variance modeling approaches: nonlinear least square (NLS), ordinary least square with log-linear regression (OLS) and nonlinear with modeled variance (MOV). Note that models containing tree total height $(H)$ as predictor were excluded here.

of these two predictors to the basic DBH model yielded a more consistent model than adding $H$ (Table S3). This pattern was true for all the three variance modeling approaches and supports having the species' identification (i.e., further assignment into SGs) and/or coherent wood density values, which is crucial when aiming for precise tree AGB predictions. Since old-growth forests comprise a mosaic of different successional stages, with trees of various architectures and sorted into different forest layers/strata, these variables are especially important when aiming for reliable AGB predictions at the landscape level (see Sect. 4.2).

Although the NLS approach fits our data set better (higher $R^{2}$ adj and lower $S_{y x} \%$ ), the assumption of a constant variance violates the natural heteroscedasticity of allometric data sets. With the log transformation of the OLS approach, homoscedasticity is reached but in a way that does not exactly reflect how variance actually changes. As previously reported for Amazon terra firme forests (Chambers et al., 2001; Lima et al., 2012), models fit with the OLS approach tend to overestimate the biomass of large-sized trees.

Indeed, the best models are obtained using the MOV and OLS approaches, in which we explicitly modeled variance depending on the main predictor (DBH). This explains why the models fit with these approaches produced more reliable (i.e., smaller differences between predictions and observations) AGB estimates as compared to those fit with the NLS approach. The NLS approach is still frequently found in the literature (Sileshi, 2014), despite the fact that assuming constant variance is not an appropriate choice for allometric data sets. We included the latter approach mainly for illustrative purposes.

Despite the highly heterogeneous nature of our data set (Table 1 and Table S1), DBH alone still captures a large fraction of the variation in AGB. This could be confirmed by lower $S_{y x} \%$ values within model series 1 in comparison to the other model series (Table 2). This result illustrates that ignoring selection criteria that capture a model's capacity to make predictions for new predictor combinations (e.g., different region or successional stage), such as the DIC or our landscape-level evaluation (see Sect. 4.2), can lead to the wrong choice. The basic models containing only DBH had a higher DIC in comparison to other model series and consequently did poorly in predicting the AGB of our different landscape scenarios (Fig. 6).

Our data set contains a large number of species, which allowed for the maximum expression of architectural attributes. In comparison to species-specific biomass estimation models (Nelson et al., 1999) or models fit from data collected in undisturbed and homogenous forests (Higuchi et al., 1998; Lima et al., 2012), we expected the addition of predictors reflecting architectural and anatomical variation to improve model parsimony. This pattern was observed when adding both SG and WD (Fig. 6 and Table S3).

The differences related to the parameters $b$ and $c$ we found among our successional groups highlighted the importance of using SG as a predictor of the architectural attributes that influence allometry, especially in disturbed or secondary forests where WD is not available (Table S3). In the models containing SG, the significant variation of the parameters $b$ and $c$ between pioneers, mid- and late-successional species highlights the importance of architectural attributes on defining allometries (Nelson et al., 1999). Often, these differences were neglected in previous studies that dealt with heterogeneous data sets and aimed at parameterizing global/pantropical biomass estimation models.

Interestingly, when compared to our two best models, the tested pantropical model from Chave et al. (2014) produced the largest bias (overestimation) for individual tree biomass prediction (Fig. S1 and Sect. 3.1). As previously mentioned, underestimation was also reported when applying the Chave et al. (2005) biomass estimation model in Atlantic Forest stands in Brazil (Nogueira Jr. et al., 2014). For our study, 
we attribute part of this pattern to strong differences in forest structure and tree allometry/architecture between our central Amazon data set and that used to parameterize the pantropical model from Chave et al. (2014). Although the DBH and $H$ range of the trees used in our study is well represented by the pantropical data set, the two data sets vary strongly with respect to the DBH and $H$ distribution of trees (Fig. S3). Our data set clearly has a much higher density of smallsized trees and a much lower density of large-sized trees. The pantropical data set comprises ca. $8 \%(n=329)$ of trees with $\mathrm{DBH} \geq 60 \mathrm{~cm}$ and mean $H$ of $39.3 \mathrm{~m}$ (and even a tree with $212 \mathrm{~cm} \mathrm{DBH}$ and another one with $70.7 \mathrm{~m} H$ ). Interestingly, none of these 329 large-sized trees were found in terra firme forests in the region of Manaus. Note that the largest tree in our data set has $85 \mathrm{~cm} \mathrm{DBH}$ and $33 \mathrm{~m} H$ (Table 1 and Table S1) and, as previously reported, trees with $\mathrm{DBH} \geq 60 \mathrm{~cm}$ account for less than $17 \%$ of the total AGB in central Amazonian terra firme forests (Vieira et al., 2004). Thus the structure and biomass of these central Amazonian forests is not well predicted from the "improved" pantropical biomass estimation model from Chave et al., 2014.

Observed differences on the relationship between predictor variables (DBH and WD) and AGB of trees from our data set and that used in the pantropical model highlight part of the variation in tree allometry and architecture that was not represented in the pantropical data set (Fig. S4). As for the differences in forest structure, these differences in tree allometry and architecture reflect typical differences in species composition among successional stages (Clark and Clark, 1992; Denslow, 1980; Marra et al., 2014). By including our two secondary forests, we added a greater proportion of allometric variation in our models compared to the Chave et al. (2014) data set (Fig. S5). Our results indicate that neglecting variations in tree allometry and architecture related to floristic composition can lead to strong bias when predicting individual tree AGB, especially when complex old-growth and secondary forests (Asner, 2013; Chambers et al., 2013; Norden et al., 2015) are not accounted for in the model parameterization.

\subsection{Landscape-level biomass predictions across scenarios}

The different combinations of floristic composition and structure (i.e., tree density and basal area) used in our virtual approach reflected forest changes along succession (Chambers et al., 2009; Marra et al., 2014; Norden et al., 2015), including realistic variations in AGB reported for central Amazon stands differing in successional stage (from early successional to old growth) (Carvalho Jr. et al., 1995; Higuchi et al., 2004; Lima et al., 2007). When taking into account the accuracy of landscape-level predictions across scenarios, the best models were those fit by using the MOV and the OLS approaches. From the MOV approach, the models M33, M43 and M23 were the first, second and third best models, respectively (Fig. 6).

Modeling the variance properly as in the MOV approach is particularly important when both small and large trees at the respective endpoints of the size predictors DBH and $H$ - are to be estimated precisely. Assuming homoscedastic variance in allometric data gives a stronger weight to the information of large trees (which have large residuals) and reduces the "strength" of the small trees (with small residuals) on the estimation of the parameters. This almost invariably leads to models that overestimate the biomass of small trees (i.e., large trees pulling the "line" upwards). This effect can be clearly seen in Fig. 4 where the NLS models dramatically overestimated the biomass, particularly in the smallsized and the early-successional scenario. The OLS approach tends to produce the opposite effect. The log transformation shrinks the size of the residuals of the large-sized trees and inflates it for the small-sized trees. The influence of positive residuals or large-sized trees that often have a strong lever is reduced, and the lever of very small trees is increased. This may (although not as extremely as in the NLS case) lead to an underestimation of the biomass of big trees. A slight tendency of this effect is also visible in Fig. 4 when the OLS and MOV models are compared in the model series 2 and 3 . The model evaluation with our virtual forests thus clearly illustrates that a balanced modeling of the variance, i.e., giving the small and large trees equal weight, is very important when (1) the design matrices are very heterogeneous or unbalanced with respect to size and when (2) predictions are made at landscape level across stands that vary in the mean size/shape of trees.

Models containing only size predictors (such as DBH) are particularly sensitive to this problem. Including SG and WD as predictors captured part of the interspecific variation in architecture and anatomy and partly alleviated the abovementioned problems of the NLS and OLS models. Thus, although a simple allometric model (e.g., $\mathrm{AGB} \sim b 1 \mathrm{DBH}^{b 2}$ ) can accurately describe the DBH: AGB relationship at the individual level (Table 3 and Table S3), our results demonstrate that reliable estimates of biomass in heterogeneous landscapes (i.e., mixtures of successional stages and tree sizes) requires correct modeling of the size-related variance (Sileshi, 2014; Todeschini et al., 2004) and including suitable predictors of species-specific attributes reflecting ecological, architectural and anatomical variation.

Our model evaluation using "virtual forests" was used to test what level of model complexity and appropriateness of variance modeling is needed to avoid "distortions" and make satisfying predictions at the fringes of our predictor space. This approach also allowed us to assess the magnitude of RMSE in model predictions in relation to the bias of these predictions. Our best performance models produced predictions with RMSE similar (i.e., M33, M43, and M23) to the bias associated to these prediction, which indicates that model deviations can be attributed to random variation 
and possibly be ignored (Gregoire et al., 2016; McRoberts and Westfall, 2014). However, since we constructed the forest scenarios with trees from our data set, this is an "internal evaluation" and not a test of model behavior in the face of new predictor combinations. Furthermore, we used DIC as parsimony-based model selection criterion, which was designed to exactly approximate this capacity and typically yields similar results as cross-validation (Wirth et al., 2004). The DIC is therefore particularly important for judging the quality of the model, especially for application in other regions or for other species. Unlike the virtual forest approach, where the DBH + WD with modeled variance (M33) appeared to be the best model (lowest bias and RMSE at the same time) (Fig. 6), the DIC invariably requires the full model complexity irrespective of whether $H$ is considered or not (Table 3).

As reported in other studies (Alvarez et al., 2012; Lima et al., 2012; Ngomanda et al., 2014; Nogueira Jr. et al., 2014), using the pantropical biomass estimation model by Chave et al. (2014) for landscape-level predictions led to strong biases in the case of our central Amazonian forest scenarios. Thus, our recommendation is not to assume that their model is equally applicable across all tropical forests, especially for secondary or hyperdiverse tropical forests. In this context, we alert researches and managers about the importance of applying local or regional generic models when estimating biomass and the importance of species composition information in plot studies.

\subsection{Suitability of the chosen predictors for practical application}

As we have seen, predicting biomass correctly at the landscape level and in particular improving performance at the fringes or outside the predictor space requires the inclusion of predictors related to species architecture (DBH in combination with $H$ (when available), WD and/or SG). Knowledge of these last two variables depends on the identification of species, further assignment into successional groups and measurement or compilation of species-specific WD values. For the purposes of our study, these variables were successfully addressed.

However, we understand that reliable biomass estimation models also require variables that can be easily and confidently acquired or measured. As we discuss below, this is not the case for the species identification, $H$ and, consequently, in many cases for WD and SG.

The tree species diversity in the Amazon is high (de Oliveira and Mori, 1999; ter Steege et al., 2013). Species identification requires extensive field work (i.e., collection of botanical samples) and joint effort of parabotanists, botanists and taxonomists. In many cases, this task might pose a major problem.

For WD, values can vary widely not only between species (Chave et al., 2006) - which we exploit in our modeling ap- proach - but also between different sites/regions (MullerLandau, 2004), within individuals of the same species or even in an individual tree (density varying along the tree bole) (Higuchi et al., 1998; Nogueira et al., 2005). Ideally, WD measures should be carried out in situ following a method that allows for sampling both heart- and sapwood. Measuring WD from nonrepresentative samples and applying measures from studies in which samples were oven dried at different temperatures can produce complication. At temperatures below $100^{\circ} \mathrm{C}$, the wood bound water content cannot be removed (Williamson and Wiemann, 2010). This requires improvement of available methods and tools (e.g., resistography, X-ray, ultrasonic tomography, near-infrared spectroscopy, acoustic/ultrasonic wave propagation and high-frequency densitometry) (Isik and Li, 2003; Lin et al., 2008; Schinker et al., 2003) that in the future may allow the measurement of WD in live trees from hyperdiverse tropical forests (thousands of species). However, the acquisition of WD data is still expensive and is not easily conducted simultaneously with forest inventories.

In the Amazon, information on WD is not available at the species level for most regions, and the available WD data have been acquired using a wide range of methods. Thus, the compilation of WD data from different sources without filtering criteria may introduce an unpredictable source of error. As a result, researchers and managers need to establish robust criteria and test whether including WD information compiled from the available literature can really increase the quality of biomass predictions (as shown in our study). These limitations become critical when adjusting biomass estimation models both from small or even large/combined data sets collected without a plot-based harvest method that allows for a landscape-level evaluation of models derived using individual trees (Carvalho Jr. et al., 1995; Higuchi et al., 1998; Lima et al., 2012; da Silva, 2007). One important result of our study is that correct assignment of species into successional groups can satisfactorily replace the use of WD despite the fact that WD and SG were not trivially correlated (Table 2).

Most of the available biomass estimation models include $H$ as a predictor. Indeed, we expected the inclusion of $H$ to substantially improve our individual tree fits and landscapelevel predictions. Although $H$ is a powerful predictor of AGB, because together with DBH it defines the slenderness of trees and also indicates the lifetime light availability (suppressed trees with typically short crowns have a high $H$ : DBH ratio), acquiring these data is still costly and difficult in tall and complex tropical forest canopies. As a consequence, $H$ is often measured imprecisely or not at all in most existing forest inventories across the Amazon. $H$ varies with plant ontogeny and can be affected by environmental and neighbor effects (Henry and Aarssen, 1999; Sterck and Bongers, 1998). Consequently, the error of AGB estimates can increase when applying $H$ values estimated from regional or global models (Feldpausch et al., 2011, 2012; Hunter et al., 2013; Santos Jr. et al., 2006). As observed in 
our (Table 2) and other data sets (Sileshi, 2014), the high collinearity between DBH and $H$ can distort coefficient values, inflate standard errors and lead to unreliable estimates. The increased availability of new tools such as Lidar can improve the resolution of data on tree height and thus biomass (Marvin et al., 2014; Sawada et al., 2015), but currently the areas where such data are available are limited. The calibration of remote-sensing-based biomass models for diverse tropical forest still relies on the degree of uncertainty associated to plot-level AGB estimates (Chen et al., 2015).

Despite uncertainties associated with global estimates of carbon stocks, tropical forests store ca. $25 \%$ of the terrestrial carbon (Bonan, 2008; Saatchi et al., 2011) and provide resources (e.g., food, fuel, timber and water) essential for humankind (Trumbore et al., 2015). Nonetheless, old-growth tropical forests are rapidly changing and degrading due to the intensification of human activities, gradual climate change and extreme weather events (FAO, 2010; IPCC, 2014). The Reducing Emissions from Deforestation and Forest Degradation (REDD+) program from the United Nations Framework Convention on Climate Change (UNFCCC) establishes rewards for actions that mitigate carbon emission through prevention of forest loss and degradation. For countries with large forest cover (e.g., Brazil and other Amazonian countries), such programs emerge as an economical alternative to historically more lucrative land uses resulting in forest degradation or suppression. However, we showed that reliable estimates of forest biomass are complex to obtain and prone to large uncertainty. Reliable predictions of biomass/carbon stocks over large regions of structurally complex and hyperdiverse tropical forests such as the Amazon still depend on the collection of plot-based allometric data and forest inventories including information on species composition, tree height and wood density, which are often unavailable or estimated imprecisely in most regions.

Natural and anthropogenic tropical secondary forests are widely distributed and account for ca. $50 \%$ of the global forest cover (FAO, 2010). Although highly productive and resilient (Poorter et al., 2016), Neotropical forests can take unpredictable successional trajectories (Norden et al., 2015). During forest succession, once floristic composition changes and structural gradients increase, allometry becomes more complex and reliable landscape-level biomass estimates may require models that include predictors approximating species-specific architecture and anatomy. Extra care should be taken when using biomass estimation models to assess biomass dynamics (e.g., biomass recovery after disturbances). Earlier stages of recovery can have a higher proportion of small trees from pioneers species, which have lower wood density (Chambers et al., 2009; Marra et al., 2014; Saldarriaga et al., 1998) and a particular type of architecture (Hallé et al., 1978; Swaine and Whitmore, 1988).

We recommend the use of the best models fit in this study when aiming for reliable landscape AGB estimations for central Amazonian terra firme forests, especially those under complex disturbance regimes and for which specific/local models are not available. When data on species composition and wood density are available or could be accurately compiled from the literature, we encourage the use of the model M33 or M23 (MOV approach). In case the MOV approach cannot be applied for model parameterization (i.e. technical or computational restrictions), the OLS is presumably more appropriate and efficient than the NLS.

\section{The Supplement related to this article is available online at doi:10.5194/bg-13-1553-2016-supplement.}

Acknowledgements. This study has been possible thanks to the extensive fieldwork carried by members of the Laboratório de Manejo Florestal (LMF) from the Instituto Nacional de Pesquisas da Amazônia (INPA). We gratefully acknowledge: Antônio F. da Silva, Armando N. Colares, Bertrán A. da Silva (in memoriam), Geraldo A. da Mota, Geraldo E. da Silva, Francinilton R. de Araújo, Francisco H. M. dos Santos, Francisco Q. Reis, José M. de Souza, José M. B. da Paz, José M. G. Quintanilha Junior, Manoel F. J. de Souza, Manoel N. Taveira, Paulo J. Q. de Lacerda (in memoriam), Pedro L. de Figueiredo (in memoriam), Romeu D. de Paiva, Sebastião M. do Nascimento, Sérgio L. Leite, Valdecira M. J. Azevedo and Wanderley de L. Reis. This study was financed by the Brazilian Council for Scientific and Technological Development (CNPq) within the projects Piculus, INCT Madeiras da Amazônia and Succession After Windthrows (SAWI) (Chamada Universal MCTI/No 14/2012, Proc. 473357/2012-7), and supported by the Max Planck Institute for Biogeochemistry within the Tree Assimilation and Carbon Allocation Physiology Experiment (TACAPE). Robinson I. Negrón-Juárez was supported by the Office of Science, Office of Biological and Environmental Research, of the US Department of Energy under contract no. DE-AC02-05CH11231 as part of Next-Generation Ecosystems Experiments (NGEE Tropics) and the Regional and Global Climate Modeling (RGCM) Program.

The article processing charges for this open-access publication were covered by the Max Planck Society.

Edited by: J. Schöngart

\section{References}

Alvarez, E., Duque, A., Saldarriaga, J., Cabrera, K., de las Salas, G., del Valle, I., Lema, A., Moreno, F., Orrego, S., and Rodríguez, L.: Tree above-ground biomass allometries for carbon stocks estimation in the natural forests of Colombia, Forest Ecol. Manag., 267, 297-308, 2012.

Amaral, D. D., Vieira, I. C. G., Almeida, S. S., Salomão, R. P., Silva, A. S. L., and Jardim, M. A. G.: Checklist of remnant forest fragments of the metropolitan area of Belém and historical value of the fragments, State of Pará, Brazil, Bol. Mus. Para. Emílio Goeldi, 4, 231-289, 2009. 
Asner, G. P.: Geography of forest disturbance, P. Natl. Acad. Sci. USA, 110, 3711-3712, 2013.

Banin, L., Feldpausch, T. R., Phillips, O. L., Baker, T. R., Lloyd, J., Affum-Baffoe, K., Arets, E. J. M. M., Berry, N. J., Bradford, M., Brienen, R. J. W., Davies, S., Drescher, M., Higuchi, N., Hilbert, D. W., Hladik, A., Iida, Y., Salim, K. A., Kassim, A. R., King, D. A., Lopez-Gonzalez, G., Metcalfe, D., Nilus, R., Peh, K. S. H., Reitsma, J. M., Sonké, B., Taedoumg, H., Tan, S., White, L., Wöll, H., and Lewis, S. L.: What controls tropical forest architecture? Testing environmental, structural and floristic drivers, Glob. Ecol. Biogeogr., 21, 1179-1190, 2012.

Bolker, B. M.: Ecological Models and Data in R, Princeton University Press, New Jersey, 2008.

Bolker, B. M., Gardner, B., Maunder, M., Berg, C. W., Brooks, M., Comita, L., Crone, E., Cubaynes, S., Davies, T., de Valpine, P., Ford, J., Gimenez, O., Kéry, M., Kim, E. J., Lennert-Cody, C., Magnusson, A., Martell, S., Nash, J., Nielsen, A., Regetz, J., Skaug, H., and Zipkin, E.: Strategies for fitting nonlinear ecological models in R, AD Model Builder, and BUGS, Methods Ecol. Evol., 4, 501-512, 2013.

Bonan, G. B.: Forests and climate change: forcings, feedbacks, and the climate benefits of forests, Science, 320, 1444-1449, doi:10.1126/science.1155121, 2008.

Bowman, D. M. J. S., Brienen, R. J. W., Gloor, E., Phillips, O. L., and Prior, L. D.: Detecting trends in tree growth: Not so simple, Trends Plant Sci., 18, 11-17, 2013.

Braga, P. I. S.: Subdivisão fitogeográfica, tipos de vegetação, conservação e inventário florístico da floresta amazônica, Acta Amaz., 9, 53-80, 1979.

Brooks, S. P. and Gelman, A.: General Methods for Monitoring Convergence of Iterative Simulations, J. Comput. Graph. Stat., 7, 434-455, 1998.

Brooks, S. P. and Roberts, G. O.: Convergence assessment techniques for Markov chain Monte Carlo, Stat. Comput., 8, 319335, 1998

Brown, S., Gillespie, A. J. R., and Lugo, A. E.: Biomass estimation methods for tropical forests with applications to forest inventory data, Forest Sci., 35, 881-902, 1989.

Carvalho Jr., J. A., Santos, J. M., Santos, J. C., Leitão, M. M., and Higuchi, N.: A tropical rainforest clearing experiment by biomass burning in the Manaus region, Atmos. Environ., 29, 2301-2309, 1995.

Chambers, J., Higuchi, N., Teixeira, L., Santos, J. dos, Laurance, S., and Trumbore, S.: Response of tree biomass and wood litter to disturbance in a Central Amazon forest, Oecologia, 141, 596611,2004

Chambers, J. Q., dos Santos, J., Ribeiro, R. J., and Higuchi, N.: Tree damage, allometric relationships, and above-ground net primary production in central Amazon forest, Forest Ecol. Manag., 152, 73-84, 2001.

Chambers, J. Q., Robertson, A. L., Carneiro, V. M. C., Lima, A. J. N., Smith, M. L., Plourde, L. C., and Higuchi, N.: Hyperspectral remote detection of niche partitioning among canopy trees driven by blowdown gap disturbances in the Central Amazon, Oecologia, 160, 107-117, 2009.

Chambers, J. Q., Negron-Juarez, R. I., Marra, D. M., Di Vittorio, A., Tews, J., Roberts, D., Ribeiro, G. H. P. M., Trumbore, S. E., and Higuchi, N.: The steady-state mosaic of disturbance and suc- cession across an old-growth Central Amazon forest landscape, P. Natl. Acad. Sci. USA, 110, 3949-3954, 2013.

Chave, J., Andalo, C., Brown, S., Cairns, M. A., Chambers, J. Q., Eamus, D., Fölster, H., Fromard, F., Higuchi, N., Kira, T., Lescure, J. P., Nelson, B. W., Ogawa, H., Puig, H., Riéra, B., and Yamakura, T.: Tree allometry and improved estimation of carbon stocks and balance in tropical forests, Oecologia, 145, 87-99, 2005.

Chave, J., Muller-Landau, H. C., Baker, T. R., Easdale, T. A., Hans Steege, T. E. R., and Webb, C. O.: Regional and phylogenetic variation of wood density across 2456 neotropical tree species, Ecol. Appl., 16, 2356-2367, 2006.

Chave, J., Coomes, D., Jansen, S., Lewis, S. L., Swenson, N. G., and Zanne, A. E.: Towards a worldwide wood economics spectrum, Ecol. Lett., 12, 351-366, 2009.

Chave, J., Réjou-Méchain, M., Búrquez, A., Chidumayo, E., Colgan, M. S., Delitti, W. B. C., Duque, A., Eid, T., Fearnside, P. M., Goodman, R. C., Henry, M., Martínez-Yrízar, A., Mugasha, W., Muller-Landau, H. C., Mencuccini, M., Nelson, B. W., Ngomanda, A., Nogueira, E. M., Ortiz-Malavassi, E., Pélissier, R., Ploton, P., Ryan, C. M., Saldarriaga, J. G., and Vieilledent, G.: Improved allometric models to estimate the aboveground biomass of tropical trees, Glob. Chang. Biol., 20, 3177-3190, 2014.

Chen, Q., Vaglio Laurin, G., and Valentini, R.: Uncertainty of remotely sensed aboveground biomass over an African tropical forest: Propagating errors from trees to plots to pixels, Remote Sens. Environ., 160, 134-143, doi:10.1016/j.rse.2015.01.009, 2015.

Clark, D. A. and Clark, D. B.: Life history diversity of canopy and emergent trees in a neotropical rain forest, Ecol. Monogr., 62, 315-344, 1992.

Clark, D. B. and Kellner, J. R.: Tropical forest biomass estimation and the fallacy of misplaced concreteness, J. Veg. Sci., 23, 11911196, 2012.

da Silva, R.: Alometria, estoque e dinânica da biomassa de florestas primárias e secundárias na região de Manaus (AM), $\mathrm{PhD}$ Thesis, Universidade Federal do Amazonas, Brazil, available at: https://www.inpa.gov.br/arquivos/Tese_Biomassa_Roseana_ Silva.pdf (last access: 5 March 2015), 2007.

da Silva, R. P., dos Santos, J., Tribuzy, E. S., Chambers, J. Q., Nakamura, S., and Higuchi, N.: Diameter increment and growth patterns for individual tree growing in Central Amazon, Brazil, Forest Ecol. Manag., 166, 295-301, 2002.

da Silva, R. P., Nakamura, S., Azevedo, C. de, Chambers, J., Rocha, R. de M., Pinto, C., dos Santos, J., and Higuchi, N.: Use of metallic dendrometers for individual diameter growth patterns of trees at Cuieiras river basin, Acta Amaz., 33, 67-84, 2003.

Denslow, J. S.: Patterns of plant species diversity during succession under different disturbance regimes, Oecologia, 46, 18-21, 1980.

de Oliveira, A. A. and Mori, S. A.: A central Amazonian terra firme forest. I. High tree species richness on poor soils, Biodivers. Conserv., 8, 1219-1244, 1999.

dos Santos, J.: Análise de modelos de regressão para estimar a fitomassa da floresta tropical úmida de terra-firme da Amazônia Brasileira, Ph.D. Thesis, Universidade Federal de Viçosa, MinasGerais, Brazil, 1996.

FAO: Global Florest Resources Assessment, FAO For. Pap., 163, 2010. 
Fearnside, P. M.: Wood density for estimating forest biomass in Brazilian Amazonia, Forest Ecol. Manag., 90, 59-87, 1997.

Feldpausch, T. R., Banin, L., Phillips, O. L., Baker, T. R., Lewis, S. L., Quesada, C. A., Affum-Baffoe, K., Arets, E. J. M. M., Berry, N. J., Bird, M., Brondizio, E. S., de Camargo, P., Chave, J., Djagbletey, G., Domingues, T. F., Drescher, M., Fearnside, P. M., França, M. B., Fyllas, N. M., Lopez-Gonzalez, G., Hladik, A., Higuchi, N., Hunter, M. O., Iida, Y., Salim, K. A., Kassim, A. R., Keller, M., Kemp, J., King, D. A., Lovett, J. C., Marimon, B. S., Marimon-Junior, B. H., Lenza, E., Marshall, A. R., Metcalfe, D. J., Mitchard, E. T. A., Moran, E. F., Nelson, B. W., Nilus, R., Nogueira, E. M., Palace, M., Patiño, S., Peh, K. S.H., Raventos, M. T., Reitsma, J. M., Saiz, G., Schrodt, F., Sonké, B., Taedoumg, H. E., Tan, S., White, L., Wöll, H., and Lloyd, J.: Height-diameter allometry of tropical forest trees, Biogeosciences, 8, 1081-1106, doi:10.5194/bg-8-1081-2011, 2011.

Feldpausch, T. R., Lloyd, J., Lewis, S. L., Brienen, R. J. W., Gloor, M., Monteagudo Mendoza, A., Lopez-Gonzalez, G., Banin, L., Abu Salim, K., Affum-Baffoe, K., Alexiades, M., Almeida, S., Amaral, I., Andrade, A., Aragão, L. E. O. C., Araujo Murakami, A., Arets, E. J. M. M., Arroyo, L., Aymard C., G. A., Baker, T. R., Bánki, O. S., Berry, N. J., Cardozo, N., Chave, J., Comiskey, J. A., Alvarez, E., de Oliveira, A., Di Fiore, A., Djagbletey, G., Domingues, T. F., Erwin, T. L., Fearnside, P. M., França, M. B., Freitas, M. A., Higuchi, N., E. Honorio C., Iida, Y., Jiménez, E., Kassim, A. R., Killeen, T. J., Laurance, W. F., Lovett, J. C., Malhi, Y., Marimon, B. S., Marimon-Junior, B. H., Lenza, E., Marshall, A. R., Mendoza, C., Metcalfe, D. J., Mitchard, E. T. A., Neill, D. A., Nelson, B. W., Nilus, R., Nogueira, E. M., Parada, A., Peh, K. S.-H., Pena Cruz, A., Peñuela, M. C., Pitman, N. C. A., Prieto, A., Quesada, C. A., Ramírez, F., Ramírez-Angulo, H., Reitsma, J. M., Rudas, A., Saiz, G., Salomão, R. P., Schwarz, M., Silva, N., Silva-Espejo, J. E., Silveira, M., Sonké, B., Stropp, J., Taedoumg, H. E., Tan, S., ter Steege, H., Terborgh, J., TorelloRaventos, M., van der Heijden, G. M. F., Vásquez, R., Vilanova, E., Vos, V. A., White, L., Willcock, S., Woell, H., and Phillips, O. L.: Tree height integrated into pantropical forest biomass estimates, Biogeosciences, 9, 3381-3403, doi:10.5194/bg-9-33812012, 2012.

Goodman, R. C., Phillips, O. L., and Baker, T. R.: The importance of crown dimensions to improve tropical tree biomass estimates, Ecol. Appl., 24, 680-698, 2014.

Graham, M. H.: Confronting multicollinearity in ecological multiple regression, Ecology, 84, 2809-2815, 2003.

Gregoire, T. G., Næsset, E., McRoberts, R. E., Ståhl, G., Andersen, H. E., Gobakken, T., Ene, L., and Nelson, R.: Statistical rigor in LiDAR-assisted estimation of aboveground forest biomass, Remote Sens. Environ., 173, 98-108, doi:10.1016/j.rse.2015.11.012, 2016.

Hallé, F.: Architecture of trees in the rain forest of Morobe District, New Guinea, Biotropica, 6, 43-50, 1974.

Hallé, F., Oldeman, R. A. A., and Tomlinson, P. B.: Tropical trees and forests: an architectural analysis, Springer-Verlag, Berlin, German Federal Republic, 1978.

Henry, H. A. L. and Aarssen, L. W.: The interpretation of stem diameter-height allometry in trees: Biomechanical constraints, neighbour effects, or biased regressions?, Ecol. Lett., 2, 89-97, 1999.
Higuchi, N., Santos, J. dos, Ribeiro, R. J., Minette, L., and Biot, Y.: Biomassa da parte aérea da vegetação da floresta tropical úmida de terra-firme da Amazônia brasileira, Acta Amaz., 28, 153-166, 1998.

Higuchi, N., Chambers, J. Q., Santos, J. dos, Ribeiro, R. J., Pinto, A. C. M., Silva, R. P. da, Rocha, R. de M., and Tribuzy, E. S.: Dinâmica e balanço do carbono da vegetaçao primária da Amazônia Central, Floresta, 34, 295-304, 2004.

Hunter, M. O., Keller, M., Victoria, D., and Morton, D. C.: Tree height and tropical forest biomass estimation, Biogeosciences, 10, 8385-8399, doi:10.5194/bg-10-8385-2013, 2013.

Huxley, J. and Teissier, G.: Terminology of relative growth, Nature, 137, 780-781, 1936.

IPCC: Guidelines for National Greenhouse Gas Inventories. IGES, Japan, available at: http://www.ipcc-nggip.iges.or.jp/ public/2006gl/index.html (last access: 5 February 2016), 2006.

IPCC: Climate Change 2014: Synthesis Report. Contribution of Working Groups I, II and III to the Fifth Assessment Report of the Intergovernmental Panel on Climate Change, Geneva, Switzerland, available at: http://www.ipcc.ch/report/ar5/syr/ (last access: 5 February 2016), 2014.

Isik, F. and Li, B.: Rapid assessment of wood density of live trees using the Resistograph for selection in tree improvement programs, Can. J. Forest Res., 33, 2426-2435, 2003.

Junk, W., Piedade, M., Shongärt, J., Cohn-Haft, M., Adeney, J., and Wittmann, F.: A classification of major naturally-occurring amazonian lowland wetlands, Wetlands, 31, 623-640, 2011.

Kammesheidt, L.: Some autecological characteristics of early to late successional tree species in Venezuela, Acta Oecologica, 21, 3748, 2000.

King, D. A.: Allometry and life history of tropical trees, J. Trop. Ecol., 12, 25-44, 1996.

Laurance, W. F., Nascimento, H. E. M., Laurance, S. G., Andrade, A., Fearnside, P. M., Ribeiro, J. E. L., and Capretz, R. L.: Rain forest fragmentation and the proliferation of successional trees, Ecology, 87, 469-482, 2006.

Lima, A. J. N., Teixeira, L. M., Carneiro, V. M. C., dos Santos, J., and Higuchi, N.: Análise da estrutura e do estoque de fitomassa de uma floresta secundária da região de Manaus AM, dez anos após corte raso seguido de fogo, Acta Amaz., 37, 49-54, 2007.

Lima, A. J. N., Suwa, R., Ribeiro, G. H. P. M., Kajimoto, T., Santos, J. dos, Silva, R. P. da, Souza, C. A. S. de, Barros, P. C. de, Noguchi, H., Ishizuka, M., and Higuchi, N.: Allometric models for estimating above- and below-ground biomass in Amazonian forests at São Gabriel da Cachoeira in the upper Rio Negro, Brazil, Forest Ecol. Manag., 277, 163-172, 2012.

Lin, C. J., Kao, Y. C., Lin, T. T., Tsai, M. J., Wang, S. Y., Lin, L. D., Wang, Y. N., and Chan, M. H.: Application of an ultrasonic tomographic technique for detecting defects in standing trees, Int. Biodeterior. Biodegrad., 62, 434-441, 2008.

Lunn, D. J., Thomas, A., Best, N., and Spiegelhalter, D.: WinBUGS - a Bayesian modelling framework: concepts, structure, and extensibility, available at: http://www.mrc-bsu.cam.ac.uk/software/ bugs/ (last access: 10 September 2015), 2000.

Marra, D. M., Chambers, J. Q., Higuchi, N., Trumbore, S. E., Ribeiro, G. H. P. M., Santos, J. dos, Negrón-Juárez, R., Reu, B., and Wirth, C.: Large-scale wind disturbances promote tree diversity in a central Amazon forest, PLoS One, 9, e103711, doi:10.1371/journal.pone.0103711, 2014. 
Marvin, D. C., Asner, G. P., Knapp, D. E., Anderson, C. B., Martin, R. E., Sinca, F., and Tupayachi, R.: Amazonian landscapes and the bias in field studies of forest structure and biomass, P. Natl. Acad. Sci., 111, E5224-E5232, 2014.

McRoberts, R. E. and Westfall, J. A.: The effects of uncertainty in individual tree volume model predictions on the uncertainty of large area volume estimates The method?, Forest Sci., 60, 3442, doi:10.5849/forsci.12-141, 2014.

Muller-Landau, H. C.: Interspecific and inter-site variation in wood specific gravity of tropical trees, Biotropica, 36, 20-32, 2004.

Negrón-Juárez, R. I., Chambers, J. Q., Guimaraes, G., Zeng, H., Raupp, C. F. M., Marra, D. M., Ribeiro, G. H. P. M., Saatchi, S. S., Nelson, B. W., and Higuchi, N.: Widespread Amazon forest tree mortality from a single cross-basin squall line event, Geophys. Res. Lett., 37, 1-5, 2010.

Nelson, B., Kapos, V., Adams, J., Oliveira, W., Braun, O., and do Amaral, I.: Forest disturbance by large blowdowns in the Brazilian Amazon, Ecology, 75, 853-858, 1994.

Nelson, B. W., Mesquita, R. C. G., Pereira, J. L. G., de Souza, S. G. A., Batista, G. T., and Couto, L. B.: Allometric regressions for improved estimate of secondary forest biomass in the central Amazon, Forest Ecol. Manag., 117, 149-167, 1999.

Ngomanda, A., Obiang, N. L. E., Lebamba, J., Mavouroulou, Q. M., Gomat, H., Mankou, G. S., Loumeto, J., Iponga, D. M., Ditsouga, F. K., Koumba, R. Z., Bobé, K. H. B., Okouyi, C. M., Nyangadouma, R., Lépengué, N., Mbatchi, B., and Picard, N.: Site-specific versus pantropical allometric equations: Which option to estimate the biomass of a moist central African forest?, Forest Ecol. Manag., 312, 1-9, 2014.

Nogueira, E. M., Nelson, B. W., and Fearnside, P. M.: Wood density in a dense forest in central Amazonia, Brazil, Forest Ecol. Manag., 208, 261-286, 2005.

Nogueira, E. M., Fearnside, P. M., Nelson, B. W., and França, M. B.: Wood density in forests of Brazil's "arc of deforestation": Implications for biomass and flux of carbon from land-use change in Amazonia, Forest Ecol. Manag., 248, 119-135, 2007.

Nogueira Jr., L. R., Engel, V. L., Parrotta, J. A., Melo, A. C. G., and Ré, D. S.: Allometric equations for estimating tree biomass in restored mixed-species Atlantic, Biota Neotrop., 14, 1-9, 2014.

Norden, N., Angarita, H. A., Bongers, F., Martínez-Ramos, M., Granzow-de la Cerda, I., van Breugelf, M., Lebrija-Trejos, E., Meavei, J. A., Vandermeer, J., Williamson, G. B., Finegan, B., Mesquita, R., and Chazdon, R. L.: Successional dynamics in Neotropical forests are as uncertain as they are predictable, P. Natl. Acad. Sci. USA, 112, 8013-8018, 2015.

Petraitis, P. S., Dunham, A. E., and Niewiarowski, P. H.: Inferring multiple causality: the limitations of path analysis, Funct. Ecol., 10, 421-431, 1996.

Poorter, L., Bongers, F., Sterck, F. J., and Wöll, H.: Architecture of 53 Rain Forest Tree Species Differing in Adult Stature and Shade Tolerance, Ecology, 84, 602-608, 2003.

Poorter, L., Bongers, F., Aide, T. M., Almeyda Zambrano, A. M., Balvanera, P., Becknell, J. M., Boukili, V., Brancalion, P. H. S., Broadbent, E. N., Chazdon, R. L., Craven, D., de AlmeidaCortez, J. S., Cabral, G. A. L., de Jong, B. H. J., Denslow, J. S., Dent, D. H., DeWalt, S. J., Dupuy, J. M., Durán, S. M., Espírito-Santo, M. M., Fandino, M. C., César, R. G., Hall, J. S., Hernandez-Stefanoni, J. L., Jakovac, C. C., Junqueira, A. B., Kennard, D., Letcher, S. G., Licona, J.-C., Lohbeck, M., Marín-
Spiotta, E., Martínez-Ramos, M., Massoca, P., Meave, J. A., Mesquita, R., Mora, F., Muñoz, R., Muscarella, R., Nunes, Y. R. F., Ochoa-Gaona, S., de Oliveira, A. A., Orihuela-Belmonte, E., Peña-Claros, M., Pérez-García, E. A., Piotto, D., Powers, J. S., Rodríguez-Velázquez, J., Romero-Pérez, I. E., Ruíz, J., Saldarriaga, J. G., Sanchez-Azofeifa, A., Schwartz, N. B., Steininger, M. K., Swenson, N. G., Toledo, M., Uriarte, M., van Breugel, M., van der Wal, H., Veloso, M. D. M., Vester, H. F. M., Vicentini, A., Vieira, I. C. G., Bentos, T. V., Williamson, G. B., and Rozendaal, D. M. A.: Biomass resilience of Neotropical secondary forests, Nature, 530, 211-214, doi:10.1038/nature16512, 2016.

R Core Team: R: A language and environment for statistical computing, available at: http://www.r-project.org (last access: 10 February 2016), 2014.

Ribeiro, G. H. P. M., Suwa, R., Marra, D. M., Kajimoto, T., Ishizuka, M., and Higuchi, N.: Allometry for juvenile trees in an Amazonian forest after wind disturbance, Japan Agricultural Research Quarterly, 48, 213-219, 2014.

Ribeiro, J. E. L. S., Hopkins, M. J. G., Vicentini, A., Sothers, C. A., Costa, M. A. da S., Brito, J. M. de, Souza, M. A. D. de, Martins, L. H. P., Lohmann, L. G., Assunção, P. A. C. L., Pereira, E. da C., Silva, C. F. da, Mesquita, M. R., and Procópio, L. C.: Flora da Reserva Ducke: Guia de Identificação das Plantas Vasculares de uma Floresta de Terra-firme na Amazônia Central, INPA, Manaus, 1999.

Saatchi, S., Harris, N., S, B., Lefsky, M., Mitchard, E., Salas, W., Zutta, B., Buermann, W., Lewis, S., Hagen, S., Petrova, S., White, L., and Silman, M.: Benchmark map of forest carbon stocks in tropical regions across three continents, P. Natl. Acad. Sci. USA, 108, 9899-9904, 2011.

Saldarriaga, J. G., West, D. C., Tharp, M. L., and Uhl, C.: LongTerm Chronossequence of Forest Succession in the Upper Rio Negro of Colombia and Venezuela, J. Ecol., 76, 938-958, 1998.

Santos Jr., U. M., Gonçalves, J. F. de C., and Feldpausch, T. R.: Growth, leaf nutrient concentration and photosynthetic nutrient use efficiency in tropical tree species planted in degraded areas in central Amazonia, Forest Ecol. Manag., 226, 299-309, 2006.

Sawada, Y., Suwa, R., Jindo, K., Endo, T., Oki, K., Sawada, H., Arai, E., Shimabukuro, Y. E., Celes, C. H. S., Campos, M. A. A., Higuchi, F. G., Lima, A. J. N., Higuchi, N., Kajimoto, T., and Ishizuka, M.: A new 500-m resolution map of canopy height for Amazon forest using paceborne LiDAR and cloud-free MODIS imagery, Int. J. Appl. Earth Obs. Geoinf., 43, 92-101, 2015.

Schietti, J., Emilio, T., Rennó, C. D., Drucker, D. P., Costa, F. R. C., Nogueira, A., Baccaro, F. B., Figueiredo, F., Castilho, C. V, Kinupp, V., Guillaumet, J.-L., Garcia, A. R. M., Lima, A. P., and Magnusson, W. E.: Vertical distance from drainage drives floristic composition changes in an Amazonian rainforest, Plant Ecol Divers., 7, 1-13, doi:10.1080/17550874.2013.783642, 2013.

Schinker, M. G., Hansen, N., and Spiecker, H.: High-frequency densitometry - a new method for the rapid evaluation of wood density variations, IAWA J., 24, 231-239, 2003.

Shugart, H. H. and West, D. C.: Forest Succession Models, Bioscience, 30, 308, 1980.

Sileshi, G. W.: A critical review of forest biomass estimation models, common mistakes and corrective measures, Forest Ecol. Manag., 329, 237-254, 2014.

Slik, J. W. F., Arroyo-Rodríguez, V., Aiba, S., Alvarez-Loayza, P., Alves, L. F., Ashton, P., Balvanera, P., Bastian, M. L., Belling- 
ham, P. J., van den Berg, E., Bernacci, L., Bispo, P. da C., Blanc, L., Bö-Gaese, K., Boeckx, P., Bongers, F., Boyle, B., Bradford, M., Brearley, F. Q., Hockemba, M. B., Bunyavejchewin, S., Matos, D. C. L., Castillo-Santiago, M., Catharino, E. L. M., Chai, S., Chen, Y., Colwell, R. K., Chazdon, R. L., Clark, C., Clark, D. B., Clark, D. A., Culmsee, H., Damas, K., Dattaraja, H. S., Dauby, G., Davidar, P., DeWalt, S. J., Doucet, J., Duque, A., Durigan, G., Eichhorn, K. A. O., Eisenlohr, P. V., Eler, E., Ewango, C., Farwig, N., Feeley, K. J., Ferreira, L., Field, R., Oliveira Filho, A. T. de, Fletcher, C., Forshed, O., Franco, G., Fredriksson, G., Gillespie, T., Gillet, J., Amarnath, G., Griffith, D. M., Grogan, J., Gunatilleke, N., Harris, D., Harrison, R., Hector, A., Homeier, J., Imai, N., Itoh, A., Jansen, P. A., Joly, C. A., Jong, B. H. J. de, Kartawinata, K., Kearsley, E., Kelly, D. L., Kenfack, D., Kessler, M., Kitayama, K., Kooyman, R., Larney, E., Laumonier, Y., Laurance, S., Laurance, W. F., Lawes, M. J., Amaral, I. L. do, Letcher, S. G., Lindsell, J., Lu, X., Mansor, A., Marjokorpi, A., Marti, E. H., Meilby, H., Melo, F. P. L., Metcalfe, D. J., Medjibe, V. P., Metzger, J. P., Millet, J., Mohandass, D., Montero, J. C., Valeriano, M. de M., Mugerwa, B., Nagamasu, H., Nilus, R., et al.: An estimate of the number of tropical tree species, P. Natl. Acad. Sci., 112, 7472-7477, 2015.

Spiegelhalter, D. J., Best, N. G., Carlin, B. P., and van der Linde, A.: Bayesian measures of model complexity and fit, J. R. Stat. Soc. B, 64, 583-639, 2002.

Sprugel, D. G.: Correcting for bias in log-transformed allometric equations, Ecology, 64, 209-210, 1983.

ter Steege, H., Pitman, N. C., Sabatier, D., Baraloto, C., Salomão, R. P., Guevara, J. E., Phillips, O. L., Castilho, C. V., Magnusson, W. E., Molino, J., Monteagudo, A., Núñez Vargas, P., Montero, J. C., Feldpausch, T. R., Coronado, E. N. H., Killeen, T. J., Mostacedo, B., Vasquez, R., Assis, R. L., Terborgh, J., Wittmann, F., Andrade, A., Laurance, W. F., Laurance, S., Marimon, B. S., Marimon, B., Vieira, I. C. G., Amaral, I. L., Brienen, R., Castellanos, H., López, D. C., Duivenvoorden, J. F., Mogollón, H. F., Matos, F. D. de A., Dávila, N., García-Villacorta, R., Diaz, P. R. S., Costa, F., Emilio, T., Levis, C., Schietti, J., Souza, P., Alonso, A., Dallmeier, F., Montoya, A. J. D., Fernandez Piedade, M. T., Araujo-Murakami, A., Arroyo, L., Gribel, R., Fine, P., Peres, C., Toledo, M., Aymard, C. G., Baker, T. R., Cerón, C., Engel, J., Henkel, T. W., Maas, P., Petronelli, P., Stropp, J., Zartman, C. E., Daly, D., Neill, D., Silveira, M., Paredes, M. R., Chave, J., Lima Filho, D. de A., Jørgensen, P. M., Fuentes, A., Schöngart, J., Cornejo Valverde, F., Di Fiore, A., Jimenez, E. M., Peñuela Mora, M. C., Phillips, J. F., Rivas, G., van Andel, T. R., von Hildebrand, P., Hoffman, B., Zent, E. L., Malhi, Y., Prieto, A., Rudas, A., Ruschell, A. R., Silva, N., Vos, V., Zent, S., Oliveira, A. A., Schutz, A. C., Gonzales, T., Nascimento, M. T., Ramirez-Angulo, H., Sierra, R., Tirado, M., Medina, M. N. U., van der Heijden, G., Vela, C. I., Torre, E. V., Vriesendorp, C., et al.: Hyperdominance in the Amazonian tree flora, Science, 342, 1243092, doi:10.1126/science.1243092, 2013.
Sterck, F. J. and Bongers, F.: Ontogenetic Changes in Size, Allometry, and Mechanical Design of Tropical Rain Forest Trees, Am. J. Bot., 85, 266-272, 1998.

Stevens, P. F.: Angiosperm Phylogeny Website, version 12, available at: http://www.mobot.org/MOBOT/research/APweb/ (last access: 10 September 2015), 2012.

Sturtz, S., Ligges, U., and Gelman, A.: R2WinBUGS: A Package for Running WinBUGS from R, J. Stat. Softw., 12, 1-16, 2005.

Suwa, R., Kajimoto, T., Ishizuka, M., Pinto, A. C. M., Trindade, A. S., Silva, R. O., and Higuchi, N.: Comparative study of forest structure between plateau and valley bottom in a central Amazonian forest, Kanto ShinrinKenkyu, 63, 85-88, 2012.

Swaine, M. D. and Whitmore, T. C.: On the definition of ecological species groups in tropical rain forests, Vegetatio, 75, 81-86, 1988.

Telles, E. C., Camargo, P. B., Martinelli, L. A., Trumbore, S. E., Costa, E. S., Santos, J., Higuchi, N., and Oliveira Jr., C.: Influence of soil texture on carbon dynamics and storage potential in tropical forest soils of Amazonia, Global Biogeochem. Cy., 17, 1-12, 2003.

Todeschini, R., Consonni, V., Mauri, A., and Pavan, M.: Detecting "bad" regression models: Multicriteria fitness functions in regression analysis, Anal. Chim. Acta, 515, 199-208, 2004.

Toledo, J. de, Magnusson, W., Castilho, C., and Nascimento, H.: Tree mode of death in Central Amazonia: Effects of soil and topography on tree mortality associated with storm disturbances, Forest Ecol. Manag., 263, 253-261, 2012.

Trumbore, S., Brando, P., and Hartmann, H.: Forest health and global change, Science, 349, 814-818, doi:10.1126/science.aac6759, 2015.

Vieira, S., de Camargo, P. B., Selhorst, D., da Silva, R., Hutyra, L., Chambers, J. Q., Brown, I. F., Higuchi, N., Santos, J. dos, Wofsy, S. C., Trumbore, S. E., and Martinelli, L. A.: Forest structure and carbon dynamics in Amazonian tropical rain forests, Oecologia, 140, 468-479, 2004.

Wickham, H.: ggplot2: elegant graphics for data analysis, Springer New York, 2009.

Williamson, B. G. and Wiemann, M. C.: Measuring wood specifc gravity...correctly, Am. J. Bot., 97, 519-524, 2010.

Wirth, C., Schumacher, J., and Schulze, E.: Generic biomass functions for Norway spruce in Central Europe - a meta-analysis approach toward prediction and uncertainty estimation, Tree Physiol., 24, 121-139, 2004.

Worbes, M., Staschel, R., Roloff, A., and Junk, W. J.: Tree ring analysis reveals age structure, dynamics and wood production of a natural forest stand in Cameroon, Forest Ecol. Manag., 173, 105-123, 2003.

Wutzler, T., Wirth, C., and Schumacher, J.: Generic biomass functions for common beech (Fagus sylvatica L.) in Central Europe predictions and components of uncertainty, Can. J. For. Res., 38, 1661-1675, 2008. 